https://doi.org/10.35219/history.2018.08

Raluca SPIRIDON*

\title{
ELIMINAREA DIN UNIVERSITĂȚI A SCRIITORILOR CU TITLURI ACADEMICE ÎN PERIOADA 1944-1948
}

\author{
The Purging from Universities of the Writers Who Held Academic Titles during \\ the Years 1944-1948
}

Abstract: One of the methods of social marginalisation of the writers who did not meet the approval of the Communist Party was their being dismissed from their academic positions in the Romanian universities.

The purging of 1944-1948 was officially aimed at those writers who had openly declared their support for the Legionaries or for Ion Antonescu government. However, equally inconvenient people were also targeted, even though they did not fall under said categories. Among the strategies used to eliminate the undesirables, one could mention the introduction of rationalisation of budget expenses in 1947 and the reorganisation of higher education by Education Law of 1948.

Keywords: communism, Romania, writer, university, purging

\section{Numirile de rectori și decani. Prima formă de încălcare a autonomiei universitare. Epurările din învățământul superior 1944-1945.}

Sistemul universitar românesc a continuat să funcționeze după 23 august 1944, în cadrul legal fixat de Legea nr. 386 relativă la organizarea învățământului superior din 19 mai $1942^{1}$ cu unele modificări intervenite la 23 noiembrie $1943^{2}$.

Potrivit acestui cadru legal, în structura învățământului superior umanist erau cuprinse următoarele instituții: Universitatea „Mihăileană” din Iași, cu facultăţile de Drept, Litere și Filozofie, Științe, Medicină umană și Facultatea de Teologie, având sediul la Cernăuți; Universitatea din București cu aceleași facultăți la care se adăugau Facultatea de Farmacie și cea de Medicină veterinară; Universitatea "Regele Ferdinand I" din Cluj-Sibiu cu Facultăţile de Drept, Filozofie şi Litere, Științe, Medicină umană. Existau, de asemenea, Conservatoare

\footnotetext{
* Consiliul Național pentru Studierea Arhivelor Securității, București.

${ }^{1}$ Monitorul Oficial nr. 118, 23 mai 1942, pp. 4 228-4 247.

${ }^{2}$ Idem, nr. 274, 23 noiembrie 1943, pp. $10839-10870$. 
Regale de Muzică și Artă Dramatică în București, Iași, Cluj-Sibiu, o Şcoală de Arhivistică în București și două Școli Superioare de Arte Frumoase în București, respectiv Iaşi.

Schimbarea alianțelor României la 23 august 1944 și proclamația regelui Mihai care anunța ,începutul unei ere noi în care drepturile și libertăţile cetățenilor sunt garantate și vor fi respectate" ${ }^{3}$ au adus cu sine și problematica epurării celor considerați a fi fost sprijinitorii regimurilor anterioare, accentuată pe fondul atmosferei de limitare a cheltuielilor bugetare, așa cum rezultă din punctele de vedere exprimate cu ocazia ședinței Consiliului de Miniștri din 31 august 1944:

„Dl. General Gheorghe Potopeanu [ministrul Economiei Naţionale şi al Finanțelor n.n.]: Situația financiară a țării este departe de a fi roză. Am reușit, prin anumite trucuri, să nu rămânem, deocamdată, descoperiți decât cu 10 miliarde, până la întâi [septembrie n.n.], pentru care n-am găsit acoperire. Însă dacă nu se vor face economii sângeroase la toate departamentele, evident trebuie să dăm drumul rotativei.

Dl. Gr. Niculescu-Buzești [ministrul Afacerilor Străine n.n.]: Suntem ținuți de diferite prescripții legale. Eu propun ca Guvernul să adopte imediat un decretlege, în baza căruia toate numirile făcute de la începuturile regimurilor de dictatură, adică de la 1938 și până acum, să fie revizuibile - pentru că nu putem scoate funcționarii, dacă nu avem un text de lege care să ne permită lucrul acesta. Odată ce am adoptat acest decret-lege, putem face economiile care se impun în împrejurările de față. Eu nu pot da funcționarii bugetari afară, căci este ilegal. Diurniști am foarte puţini, dar bugetari [am mulți n.n.], am o pletoră de instituții create care nu prezintă nici o utilitate. $[\ldots . .$.

Dl. G-ral N. Marinescu [ministrul Muncii și Sănătății Publice n.n.] : În categoria funcționarilor numiţi în ultima vreme intră serii întregi de oameni. S-au publicat concursuri de medici, când medicii erau pe front și nu se puteau prezenta. A fost un protest general în toată țara. Și atunci ce facem cu aceste concursuri? Le abrogăm? Renunțăm la ele?

Dl. Gr. Niculescu-Buzești: Așa s-a făcut și la universități și la școli. [....]

Dl. G-ral N. Marinescu: Una este funcționarul și una este medicul primar numit prin concurs.

Dl. Gr. Niculescu-Buzești: Tot numire este și aceea.

Dl. G-ral N. Marinescu: Trebuie vorbit și despre concursurile care s-au ținut până acum.

D1. C.C. Brătianu: Dar cu profesorii de la Universitate ce facem?

Dl. Gr. Niculescu-Buzești: Tot numiri sunt și acelea.

\footnotetext{
${ }^{3}$ Idem, nr. 197 Bis, 24 august 1944, p. 6198.
} 
D1. Viceamiral Alexandru Gheorghiu: Legea, de principiu, propusă de dl. ministru Niculescu-Buzești este foarte bună: numirile și înaintările făcute de la 1938 încoace sunt revizuibile"4.

Într-un astfel de context dominat de ideea lustrației, accentuat şi de necesitatea restrângerii cheltuielilor bugetare, în toamna anului 1944 au fost emise nu mai puțin de trei acte normative, după cum urmează: Legea nr. 461 din 19 septembrie $1944^{5}$ privind purificarea aparatului de stat; Legea $\mathrm{nr} .486$ din 8 octombrie $1944^{6}$ privitoare la purificarea administrațiilor publice, care aducea clarificări suplimentare referitoare la intențiile legiuitorului, și Legea nr. 594 din 24 noiembrie $1944^{7}$ pentru modificarea unor articole din Legea nr. 486/1944.

Purificarea aparatului de stat, iar în ceea ce ne interesează a învățământului universitar, nu era necunoscută în România. Perioada regimului autoritar a lui Carol II a deschis prin Decretul-Lege nr. 2650 din 8 august 1940 privitor la starea juridică a locuitorilor evrei din România $^{8}$ calea excluderilor pe criterii etnice, excluderi continuate de Ion Antonescu, inclusiv după înlăturarea legionarilor de la putere ${ }^{9}$. Noutatea introdusă de legionari, inspirată din legislația nazistă a celui de-al Treilea $\operatorname{Reich}^{10}$, a fost reprezentată de inițierea unei ample revizuiri a corpului universitar ${ }^{11}$.

\footnotetext{
${ }^{4}$ Stenograma ședinței Consiliului de Miniștri din 31 august 1944 în Stenogramele Ședințelor Consiliului de Miniștri Guvernarea Constantin Sănătescu, vol. 1, (august-noiembrie 1944), ediție de documente întocmită de Marcel-Dumitru Ciucă, București, Editura Saeculum I.O., 2011, pp. 68-69.

${ }^{5}$ Monitorul Oficial nr. 216, 19 septembrie 1944, pp. 6 348-6 349.

${ }^{6}$ Idem, nr. 233, 8 octombrie 1944, pp. 6 559-6 560.

${ }^{7}$ Idem, nr. 273, 24 noiembrie 1944, p. 7613.

${ }^{8}$ Idem, nr. 183, 9 august 1944, pp. 4 079-4 086; vezi și Lya Benjamin (ed), Evreii din România între anii 1940-1944, vol. 1, Legislația antievreiască, București, Editura Hasefer, 1993, document 3, pp. 37-50.

${ }^{9}$ Comisia internațională pentru studierea Holocaustului în România, Raport final, Iași, Editura Polirom, 2005, p. 180.

10 Denotația conceptului de epurare fusese inspirată din „Legea pentru confirmarea funcționarilor publici” (7 aprilie 1933), emisă imediat după instalarea lui Hitler în fruntea Reich-ului, lege ce a fãcut posibilă în Germania nazistă concedierea sau pensionarea persoanelor care nu prezentau încredere și, prin paragraful referitor la originea ariană, înlăturarea evreilor (vezi, pe larg, Norbert Frei, Statul Führerului. Regimul național-socialist 1933-1945, București, Editura Runa - Grupul Editorial Corint, 2007, pp. 68-69).

${ }^{11}$ Românizarea învățământului universitar românesc, atât a corpului universitar cât și a celui studențesc a fost amplu analizată de Maria Someșan, Universitate și politică în deceniile 4-6 ale secolului XX. Episoade și documente, București, Editura Universității din București, 2004; Ovidiu Bozgan, Învățământul superior Putere și Universitate în România anilor 19401947 în Academia Română, Secția de Științe și Arheologie, Istoria românilor, vol. IX: România în anii 1940-1947, coord. Dinu C. Giurescu, membru titular al Academiei Române, Florin Șperlea, secretar, București, Editura Enciclopedică, 2008, pp. 910-913 și Gheorghe
} 
În privința acestui ultim aspect, după eșecul rebeliunii din 21-23 ianuarie 1941, cursul său a fost abandonat, viața universitară rămânând cu anumite limite destul de autonomă, evident respectând condiția de a nu pune în discuție așa cum afirma istoricul Lucian Boia „legitimitatea regimului, alianța cu Germania sau dreptatea României în război”"12.

La sfârșitul celui de-al Doilea Război Mondial, epurările capătă un cu totul alt sens în țările care, fie au cunoscut ocupația nazistă, fie au fost aliate ale Germaniei și anume restabilirea încrederii în instituțiile statului prin înlăturarea sprijinitorilor regimurilor ce colaboraseră cu aceasta. În România, imediat după 23 august 1944, atunci când se spera cu sinceritate în reinstaurarea democraţiei de tip liberal, epurările au fost invocate de toate forțele politice ca fiind necesare. Sub semnătura lui Lucrețiu Pătrășcanu, reprezentant al Partidului Comunist, ajuns în poziția cheie de ministru al Justiției, procesul va începe însă să capete treptat o pronunțată valență politică. Pentru moment, la sfârșitul anului 1944, după legiferări succesive, sfera aplicabilității legii începe să se extindă: dispare limita temporală a celor supuși epurării, iar categoriile vizate de aceasta devin tot mai numeroase.

Legea $n r .594$ din 24 noiembrie 1944 pentru modificarea unor articole din Legea nr. 486/1944 privitoare la purificarea administraţiilor publice, viza următoarele persoane: „vor fi licențiați din serviciu fără nicio indemnitate, indiferent de data la care au fost numiți, încadrați sau angajați, funcționarii care: a) S-au pus prin acțiuni proprii, sub orice formă, în slujba hitlerismului și a fascismului, slujind astfel interese străine de acelea ale națiunii române; b) Au militat sub orice formă în vreo organizație politică sau paramilitară, legionară, fascistă sau hitleristă, sau au pregătit calea instaurării dictaturilor de tip fascist în România; c) au militat propagând idei contra principiilor democratice, ori influenţați de asemenea concepții, în exercițiul funcțiunii lor, au săvârșit presiuni, acte de teroare, schingiuiri și omoruri"'13.

Mai întâi de toate, existau două măsuri care echivalează cu epurările, constituind în acelaşi timp un punct de plecare pentru aplicarea mai mult decât extensivă a epurărilor, atunci când în fruntea instituțiilor din învățământul superior ajungeau universitari cu o cunoscută orientare de stânga. În primul rând este vorba despre Decretele nr. 1.900 și nr. 1901 din 14 octombrie 1944 prin care au fost înlocuiți rectorii și decanii ${ }^{14}$, respectiv directorii școlilor speciale ${ }^{15}$ și două decizii

Iacob (coord.), Universitatea din Iași: (1860-2010): facultăți, profesori, școli științifice, Iași, Editura Universității „Al. I. Cuza”, 2011.

${ }^{12}$ Lucian Boia, Capcanele istoriei Elita intelectuală românească între 1930 și 1950,

București, Editura Humanitas, 2011, pp. 158-244.

${ }^{13}$ Monitorul Oficial, nr. 273, 24 noiembrie 1944, p. 7613.

${ }^{14}$ Idem, nr. 238, 14 octombrie 1944, pp. 6 651-6 652. 
ministeriale privind schimbarea prorectorilor şi prodecanilor ${ }^{16}$. La acestea s-a adăugat una care îi viza pe subdirectorii școlilor speciale ${ }^{17}$. În al doilea rând, este emisă Legea nr. 596 din 25 noiembrie 1944 pentru încetarea mandatelor membrilor aleși în Senatele universitare pentru a se proceda la „noi alegeri" ${ }^{18}$.

Lista completă a numirilor de rectori şi decani până la data de 23 mai 1945 se prezenta astfel: Daniel Danielopol (după 10 noiembrie 1944, Simion Stoilov), rector al Universității din București, Vasile Ispir, decan al Facultății de Teologie din București, George Fotino, decan al Facultății de Drept din București, Teofil Sauciuc Săveanu, decan al Facultăţii de Litere și Filozofie din București (din 23 martie 1945, Alexandru Rosetti ${ }^{19}$ ), Simion Stoilov, decan al Facultății de Științe din București, înlocuit de Gheorghe Vrânceanu ${ }^{20}$, Gr. T. Popa, decan al Facultăţii de Medicină din București, Constantin Bordeianu, decan al Facultății de Farmacie din București, M. Ciucă, decan al Facultății de Medicină Veterinară din București, Alexandru Myller, rector al Universităţii din Iași, Constantin Angelescu, decan al Facultăţii de Drept din Iași, Alexandru Claudian, decan al Facultății de Litere și Filozofie din Iași (V. Pavelcu din 2 noiembrie 1944) $)^{21}$, Radu Cernătescu, decan al Facultății de Litere și Filozofie din Iași, Alexandru Țupa, decan al Facultății de Medicină din Iași, Vasile Loichiță, decan al Facultății de Teologie din Iași, Alexandru Borza, rector al Universității din Cluj (din 23 martie 1945, Emil Petrovici ${ }^{22}$ ), Romulus Boilă, decan al Facultății de Drept din Cluj (înlocuit în 23 martie 1945 cu Eugeniu Speranția ${ }^{23}$ ), Constantin Daicoviciu, decan al Facultății de litere și Filozofie din Cluj, Theodor Angheluță, decan al Facultății de Științe din Cluj (în locul său, din 3 februarie 1945 a fost desemnat V. Stanciu ${ }^{24}$ ), Ion Goia, decan al Facultăţii de Medicină din Cluj (în urma demisiei sale a fost numit la 17 ianuarie 1945, M. Kernbach). Alături de aceștia, sunt numiți Alexandru Sacerdoțeanu la Școala de Arhivistică din București, Mihail Jora, Sabin Drăgoi și Mircea Bârsan la Conservatoarele de Muzică și Artă Dramatică din București, Cluj-Sibiu și Iași, Jean Al. Steriade și Roman Simionescu (din 11 noiembrie 1944, Ion Irimescu) la Școlile Superioare de Arte Frumoase din București, respectiv Iași.

\footnotetext{
${ }^{15}$ Ibidem..

${ }^{16}$ Idem, nr. 255 din 3 noiembrie 1944, p. 7081.

${ }^{17}$ Ibidem, pp. 7 081-7 082.

${ }^{18}$ Idem, nr. 274, 25 noiembrie 1944, p. 7628.

${ }^{19}$ Idem, nr. 74, 30 martie 1945, p. 2425.

${ }^{20}$ Idem, nr. 277, 29 noiembrie 1944, p.7 703.

${ }^{21}$ Idem, nr. 262, 11 noiembrie 1944, p. 7291.

${ }^{22}$ Idem, nr. 74, 30 martie 1945, p. 2425.

${ }^{23}$ Ibidem, pp. 2 425-2 426.

${ }^{24}$ Idem, nr. 27, 3 februarie 1945, p. 730.
} 
Acest prim pas fiind făcut, posibil, prin decizie a ministrului Culturii Naţionale și Cultelor, imediat după 14 octombrie 1944 au fost constituite comisii de epurare.

Delegat rector al Universității din București la 10 noiembrie $1944^{25}$ și numit în funcție ca titular la 29 noiembrie $1944^{26}$ în locul lui Daniel Danielopol, devenit ministru al Sănătății în al doilea guvern Sănătescu, Simion Stoilov va prezida comisia de la Universitatea din București, ceilalți doi membri fiind profesorii Alexandru Rosetti și P.P. Stănescu.

La Universitatea din Iași, comisia de epurare a fost constituită din Alexandru Myller, în calitate de rector al Universității, Iorgu Iordan și Gheorghe Zane. În urma demisiei acestuia din urmă, la 23 ianuarie 1944, comisia era întregită de Andrei Oțetea $^{27}$.

În cazul Universităţii „Ferdinand I”, atunci când aceasta funcționa încă la Sibiu, componența comisiei de epurare era următoarea: rectorul Alexandru Borza, Constantin Daicoviciu și Tiberiu Moșoiu. La 5 februarie 1945, în urma demisiei profesorului Tiberiu Moșoiu este numit Liviu Rusu, profesor la Facultatea de Filozofie şi Litere ${ }^{28}$ iar înlocuirea lui Alexandru Borza din poziţia de rector al Universității „Ferdinand I” cu Emil Petrovici, a atras după sine și schimbarea sa din fruntea respectivei comisii.

Înainte ca aceste comisii să-și înceapă efectiv activitatea intervine o mutație instituțională majoră, care nu poate fi ignorată, și anume reorganizarea ministerelor în contextul formării celui de al doilea guvern, de această dată politic, Constantin Sănătescu.

Ministerul Culturii Naţionale și al Cultelor ${ }^{29}$ se scindează în Ministerul Educației și Ministerul Cultelor și Artelor, portofoliul educației fiind deținut până la abdicarea forțată a Regelui Mihai de către Ștefan Voitec, vechi social-democrat și membru în comitetul de conducere al partidului.

Interesul major al acestuia a fost îndreptat în primul rând spre atragerea unui mare număr de preoți, profesori și învățători în rândurile formațiunii politice din care făcea parte, dată fiind influența acestora în zonele rurale și spre crearea unor rețele de dominare și relații politice personale prin numirea unor social-democrați în posturi de inspectori, pentru ca aceștia, la rândul lor, să numească aderenți ai

\footnotetext{
${ }^{25}$ Idem, nr. 276, 28 noiembrie 1944, p. 7681.

${ }^{26}$ Ibidem, p. 7703.

${ }^{27}$ Idem, nr. 22, 29 ianuarie 1945, p. 567.

${ }^{28}$ Idem, nr. 28, 5 februarie 1945, p. 769.

${ }^{29}$ Legea nr. 494 din 1 iunie 1941 organiza Ministerul Culturii Naționale și Cultelor în trei subsecretariate de stat: Subsecretariatul de Stat al Sccoalelor, Subsecretariatul de Stat al Educației Extrașcolare, Subsecretariatul de Stat al Cultelor și Artelor (Idem, nr. 127, 1 iunie 1941, pp. 2 969-2 978).
} 
partidului, în toate organele de conducere din învățământ. Așa cum transpare dintr-o Notă întocmită la 11 august 1945 de fostul Serviciu Special de Informații, infiltrat de comuniști după 23 august 1944: „,scheletul organizațiilor din orașele de provincie și sate ale Partidului Social-Democrat era format din preoți, profesori și învățători. Numai la Congresul Învățătorilor care a avut loc în zilele de 3-5 aprilie 1945, s-a stabilit că Partidul Social-Democrat avea în organizația sa 466 de învăţători din București și 5104 în restul țării, ceea ce face peste 30\% din totalitatea învățătorilor. De atunci numărul acestora a crescut foarte mult. Ștefan Voitec a folosit, pentru a ajunge la acest rezultat, un număr de fruntași ai învățătorilor cu care a pus bazele, Organizației Centrale a Învățătorilor socialiști cu sediul în str. Sf. Apostoli nr. 12. Aceștia și-au ales un comitet central de conducere și au dezvoltat în țară acțiuni de organizare a cadrelor Partidului Social-Democrat. Ei erau: Mircea Ispir, C. PopescuTecuci, Constantin Enescu Bughea, Ilie Tulbureanu, Ion Colin, Petre Iosif, Constantin Luchian, C. Mateescu, P. Niţu, Constantin Alexandrescu, Sever Pană, Alex. Alexandrescu, Ana Ghiță, Maria Linte, Gr. Serada, Iosif Dumitrescu, Irina Rusu, Emilia Ignat, Constantin Munteanu. Un număr important de preoți s-a înscris în același mod în Partidul Social-Democrat" "30. În nota sus-menționată, referințele la deciziile lui Ștefan Voitec privind învățământul universitar lipsesc întru totul, ceea ce ne face să conchidem că nu era una dintre preocupările sale majore. Urmărind evoluția învățământului superior, se poate afirma că Ștefan Voitec a limitat unele excese „lustraționiste”, însă numirea unor universitari recunoscuți drept militanți sau simpatizanți comuniști în posturi de conducere sau ca membri în comisiile de epurare sau în Senatele universitare a urmărit întocmai planurile P.C.R. ${ }^{31}$.

O radicală operațiune de „curăţire”, pornită de reprezentanţii comuniști în guvern, a dat naștere și unei comisii însărcinată cu revizuirea ,actelor ilegale și de prigoană săvârșite prin procese disciplinare sau altfel împotriva profesorilor democrați, pentru ideile lor politice sub regimurile dictatoriale, cu sancționarea

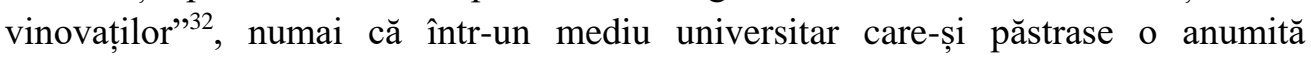
autonomie a rămas doar la nivel de intenții, apoi reintegrarea profesorilor sau

\footnotetext{
${ }^{30}$ ACNSAS, fond Documentar, dosar nr. 13 576, vol. 10, ff. 4-5.

${ }^{31}$ Vladimir Tismăneanu, Dorin Dobrincu, Cristian Vasile (editori), Raport final, Comisia prezidențială pentru analiza dictaturii comuniste din România, București, Editura Humanitas, 2007, p. 289.

${ }^{32}$ Decizia nr. 164.885 din 14 noiembrie 1944 a Ministerului Educației Naționale privind instituirea unei comisii însărcinată a revizui actele ilegale săvârșite împotriva profesorilor democrați. Din respectiva comisie făceau parte: P.P. Stănescu, secretar general al Subsecretariatului de Stat al Educației Extrașcolare, președinte, Iorgu Iordan și Mihail Cruceanu, membri (Monitorul Oficial, nr. 271, 22 noiembrie 1944, p. 7 554).
} 
docenților evrei a depins și de o anumită doză personală de acceptare socială a acestora.

Teribil dezamăgit de neputinţa exercitării funcției sale în această comisie, Iorgu Iordan a privit acest lucru drept o inconveniență fatală: „la Ministerul Educației Naționale am lucrat un timp ca membru al unei comisii însărcinate să examineze ilegalitățile şi nedreptățile săvârșite de regimurile trecute (în domeniul învăţământului) din motive rasiste sau strict politice. Ostenelile mele de a ajuta câțiva oameni loviți, din cauze străine de știință, de școală sau strict politice s-au izbit de «fanatismul» unui coleg, de altfel foarte vechi membru de partid. Îi spun «fanatism» atitudinii sale intransigente, fiindcă nu mi-o pot explica altfel. M-a durut dârzenia lui, care mi s-a părut aproape dușmănoasă sau cel puțin răutăcioasă, în cazul lui Filip Horovitz, doctor în Istorie și cu examenul de docent trecut în condițiile legii. Doctoratul și titlul de docent și le luase la Iași, unde îl apreciau, datorită valorii lui științifice, chiar profesorii cunoscuți ca antisemiţi. Nicolae Iorga însuși a recenzat favorabil una sau două lucrări ale lui. Ca docent avea dreptul să țină cursuri «libere», dar pentru aceasta trebuia o autorizație din partea Ministerului Educației Naționale, care i-a fost, bineînțeles refuzată et pour cause ${ }^{\text {"33 }}$.

La nivel juridic însă, legislația antievreiască este anulată pas cu pas, aspect pus cumva în umbră de multitudinea și rapiditatea desfăşurării evenimentelor de pe scena politică, dar circumscris unui mecanism de reintegrare socială, specific sfârşitului de conflagrație mondială în toată Europa.

Legea 466 din 22 septembrie 1944 abroga dispozițiile Decretului-Lege nr. 3438/1940 pentru reglementarea situației evreilor în învățământ și ale DecretuluiLege nr. 377/1941 privitor la unele dispoziții referitoare la învăţământul particular, precum și orice alte dispoziții din decizii și regulamente ministeriale care conțineau interdicții cu privire la accesul evreilor în învățământul de stat, confesional sau particular. Totodată, erau reprimiți în învățământ membri titulari ai corpului didactic al învățământului de toate gradele care fuseseră excluși din sistemul educaţional ${ }^{34}$. Era un efort al primului guvern Constantin Sănătescu de restabilire a ordinii și normalității. În schimb, un alt tip de evenimente, mai puțin abordat până acum, și anume reintegrarea în învățământ a acelor simpatizanți de stânga, pe care

\footnotetext{
${ }^{33}$ Iorgu Iordan, Memorii, vol. 3, București, Editura Eminescu, 1979, p. 23.

${ }^{34}$ Monitorul Oficial nr. 228, 3 octombrie 1944, p. 6498 și Decizia nr. 158514 în Monitorul Oficial nr. 263, 13 noiembrie 1944, pp. 7 311-7 312. Cea de-a doua decizie venea cu precizări suplimentare: se renunța la viza din partea ministerului pentru înscrierea în școlile de stat a elevilor și studenților care urmaseră forme de învățământ particulare evreiești între 1940-1944 sau majora condițiile limitative de vârstă cu încă 4 ani, pentru bacalaureații evrei care din cauza măsurilor rasiale, nu avuseseră posibilitatea să urmeze cursuri universitare. Prevederi specifice au fost incluse și în Legea $n r .641$ pentru abrogarea măsurilor legale antievreiești (Idem, nr. 294, 19 decembrie 1944, pp. 8 233-8 239).
} 
schimbarea alianțelor României i-a prins internați în lagăre de concentrare, necesită o explicație aparte. Sub impactul Actului de la 23 august 1944 și în speranța revenirii României la o organizare democratică sunt emise Decretul-Regal nr. 1624 pentru amnistia generală politică, militară și agrară și Legea nr. 442 pentru desființarea lagărelor de internare, ai căror principali beneficiari au fost comuniștii, în timp ce legionarii au fost exceptați de la amnistie și implicit eliberarea din lagăre. Trecut în ilegalitate încă din 1924, pe de o parte Partidul Comunist rămăsese o formațiune politică nesemnificativă și, pe de altă parte, puțini intelectuali riscaseră un conflict deschis cu statul român astfel încât cazurile de condamnări în rândul simpatizanților de procomuniști au fost destul de rare. Așa se face că după 23 august 1944, ca efect al legislației sus-menționate, sunt reintegrați în domeniile de activitate în care funcționaseră, Mircea Biji şi Mihail Levente de la Institutul Central de Statistică, Barbu Zevedei, asistent la catedra de Filozofia Culturii de la Facultatea de Litere și Filozofie a Universității „Regele Ferdinand” din Cluj ${ }^{35}$ şi Petre Constantinescu-Iași, profesor universitar la catedra de Istoria Artelor de la Facultatea de Litere și Filozofie din București ${ }^{36}$. Despre o situație particulară și singulară se poate vorbi în cazul profesorului Constantin Parhon, reintegrat în învățământ la catedra de Endocrinologie de la Facultatea de Medicină din București prin derogare de la dispozițiile art. 61-62 și 89 din Legea de organizare a Învățământului Superior, în cazul său aceasta fiind o răsplată pentru implicarea sa în obiectivele politice lansate de comuniști ${ }^{37}$. În general s-a evitat prelungirea activitătiii profesorilor care îndeplineau condițiile de pensionare.

Anul universitar 1944-1945 se deschide la 15 ianuarie $1945^{38}$. Efortul de război al României, continuarea operațiunilor militare dincolo de granițele naționale, prezența trupelor sovietice în România și rechiziţiile pe care le implica aceasta, o inflație care își arăta deja efectele au fost unele dintre cauzele amânării începerii cursurilor universitare.

Într-un efort recuperator, de lărgire a accesului la învățământul universitar după patru ani de război care nu au permis celor mobilizaţi să poată urma cursuri superioare, au fost desființate examenele de admitere la Facultățile de Teologie, Drept, Litere, Filozofie și Științe în toate Universitățile din țară ${ }^{39}$. În anul următor, înscrierile pentru anul întâi la Facultăţile de Drept, Litere-Filozofie și Științe din București, din motive care au ținut de supraaglomerarea Universității s-au făcut pe

\footnotetext{
${ }^{35}$ Idem, nr. 246, 24 octombrie 1944, p. 6833.

${ }^{36}$ Idem, nr. 282, 5 decembrie 1944, p. 7903.

${ }^{37}$ Idem nr. 69, 24 martie 1945, p. 2216.

${ }^{38}$ Ilie Barbu, Azi se deschid Universitățile în „Scânteia”, nr. 110, 16 ianuarie 1945, p. 3.

${ }^{39}$ Monitorul Oficial, nr. 288, 12 decembrie 1944, p. 8071.
} 
baza unui examen de admitere în limita locurilor fixate de către instituția de învățământ superior. Totodată, fundamentele legale, elaborate în toamna anului 1944 încep să se materializeze la începutul anului 1945. După o stigmatizatoare campanie de presă $\breve{a}^{40}$, primele epurări publicate, pentru motive care au ținut de natura stridentă a apartenenței la Mișcarea Legionară sau a implicării în direcțiile de acțiune ale regimului antonescian, au fost cele de la Universitatea din București, după cum urmează: Mihai Antonescu, Gheorghe Alexianu, profesori titulari, cărora li se adăugau: Ovidiu Vlădescu și Radu Meitani, conferențiari definitivi la Facultatea de Drept; Petre Panaitescu, Ion Petrovici, Alexandru Marcu, Nicolae Herescu, profesori titulari la Facultatea de Litere și Filozofie; Nichifor Crainic, profesor la Facultatea de Teologie; Dr. Petre Tomescu și Virgil Nitzulescu, profesori titulari la Facultatea de Medicină Umană ${ }^{41}$. Din rândul asistenților universitari au fost vizați de acest proces, Nicolae Roșu, Șerban Milcoveanu și Gheorghe Alexandru Buttu, asistenţi de Facultatea de medicină, urmați de Leon Țopa, Radu Demetrescu-Gyr și Dumitru Şandru, asistenţi la Facultatea de Litere şi Filozofie ${ }^{42}$. Aristide Bazilescu, profesor titular la Facultatea de Drept a fost licențiat mai târziu ${ }^{43}$ după cum în vara anului 1945 se produce și îndepărtarea din funcție pe timp de un an a lui Gheorghe Manu, conferențiar definitiv la Facultatea de Științe București ${ }^{44}$ dar și licențierea lui Vladimir Dumitrescu, director al Muzeului Național de Antichității ${ }^{45}$.

Pe de altă parte, în toamna anului 1944, pe lângă înlocuirea rectorilor/prorectorilor, decanilor și prodecanilor a fost revendicată schimbarea Senatelor universitare. Date complete avem doar în ceea ce privește componența Senatului Universității București, unde au fost numiţi prin decizie ministerială cu încălcarea art. 138 din Legea nr. 386 privind organizarea învățământului superior, care prevedea că membrii acestora erau aleși pe 2 ani de Consiliul Profesoral, câte unul de fiecare facultate, următorii profesori titulari: Părintele profesor, Grigore Pisculescu (Gala Galaction) din partea Facultății de Teologie; Barbu Dimitrescu, din

\footnotetext{
${ }^{40}$ Alături de „Scânteia” și „România Liberă”, atacuri dure la adresa mai multor universitari (Ion Petrovici, Sextil Pușcariu, Alexandru Marcu, Nicolae Herescu) sunt publicate într-un organ de presă nou creat și anume ziarul „Victoria” (20 octombrie 1944 - 28 martie 1948), sub direcția lui N.D. Cocea.

${ }^{41}$ Monitorul Oficial nr. 20, 26 ianuarie 1945, p. 494; Asupra licențierii lui Virgil Nitzulescu s-a revenit, îndepărtarea din serviciu reducându-i-se pe timp de un an, începând cu data de 26 ianuarie 1945 (Idem, nr. 127, 7 iunie 1945, p. 4 741).

${ }^{42}$ Idem, nr. 21 din 27 ianuarie 1945, p. 532. În cazul lui Dumitru Şandru se va reveni asupra acestei decizii, îndepărtarea sa fiind redusă la un an, până la data de 27 ianuarie 1946, când este reîncadrat pe postul său de la catedra profesorului Sever Pop (Idem, nr. 128 din 5 iunie 1946, p. 5718 ).

${ }^{43}$ Idem, nr. 74, 30 martie 1945, p. 2425.

${ }^{44}$ Idem, nr. 134, 16 iunie 1945, p. 5054.

${ }^{45}$ Idem, nr. 159, 17 iulie 1945, p. 6065.
} 
partea Facultăţii de Drept; Prof. N. Bănescu din partea Facultăţii de Litere și Filozofie; Gh. Demetrescu din partea Facultății de Științe; C. Ionescu-Mihăești din partea Facultății de Medicină; G. Niculescu, Facultatea de Farmacie; Radu Vlădescu - Facultatea de Medicină veterinară ${ }^{46}$.

Date certe referitoare la alcătuirea Senatului Universității Cuza Vodă din Iași avem doar pentru Ioan Gh. Botez, delegat al Facultății de Științe ${ }^{47}$, I. Enescu din partea Facultății de Medicină ${ }^{48}$ și Ioan Popoviciu din cea a Facultății de Drept ${ }^{49}$. O situație asemănătoare am întâlnit și în privința Senatului Universității din Cluj, unde există informații doar despre Fl. Ștefănescu-Goangă, delegat din partea Facultății de Litere și Filozofie ${ }^{50}$ și Aristide Grădinărescu, reprezentând Facultatea de Științe $e^{51}$.

În strânsă legătură cu evoluția vieții politice din România și formarea guvernului pro-comunist condus de dr. Petru Groza, după 6 martie 1945 procesul de epurare este continuat cu o și mai mare intensitate. Alături de Legea 217 din 30 martie 1945 care includea acum în sfera persoanelor epurabile pe toți aceia care ,au luat atitudine antidemocratică" ${ }^{, 52}$ sunt constituite comisii informative pentru purificarea personalului didactic și administrativ al Universităților. În cazul multora dintre membri acestora era vorba de reconfirmări după unele demisii de onoare și/sau înlocuiri de rectori și decani ${ }^{53}$.

Istoricii care s-au aplecat asupra transformărilor vieții universitare românești în perioada 1944-1948 sunt unanimi în a aprecia că, una dintre cele mai drastice epurări s-a produs în mediul universitar ieșean după intrarea în comisia de epurare a lui Andrei Oțetea și Iorgu Iordan. Până atunci „Myller s-a arătat mai înțelegător, iar

\footnotetext{
${ }^{46} \mathrm{Idem}, \mathrm{nr} .12,16$ ianuarie 1945, pp. 286-287.

${ }^{47}$ Idem, nr. 35, 13 februarie 1945, p. 1007.

${ }^{48}$ Idem, nr. 47, 27 februarie 1945, pp. 1492.

${ }^{49}$ Idem, nr. 55, 8 martie 1945, p. 1737.

${ }^{50}$ Idem, nr. 67, 23 martie 1945, p. 2147.

${ }^{51}$ Idem, nr. 110, 18 mai 1945, p. 4052.

${ }^{52}$ Maria Someșan, Mircea Iosifescu, Modificarea structurii Universității în anii consolidării sistemului comunist în ed. Romulus Rusan, Anul 1948 - Instituționalizarea comunismului, Seria ,Analele Sighet 6”, București, Fundația Academia Civică, 1998, p. 454.

${ }^{53}$ La București, comisia era formată din: Simion Stoilov, rectorul Universității, președinte, Alexandru Rosetti, decanul Facultății de Litere și Filozofie și P.P. Stănescu de la Facultatea de Farmacie, membri. După unele demisii de onoare, la Cluj în alcătuirea respectivului organism intrau Emil Petrovici, propulsat rector al Universității, președinte, Constantin Daicoviciu, de la Facultatea de Litere și Filozofie, Coriolan Drăgulescu, șef de lucrări la Facultatea de Științe, membri (Monitorul Oficial nr. 109, 17 mai 1945, p. 3 994). În fruntea comisiei informative pentru purificarea personalului didactic și administrativ al Universității de la Iași ajungeau Iorgu Iordan, rectorul Universității, Andrei Oțetea, de la Facultatea de Litere și Filozofie și Coriolan Drăgulescu, de la Facultatea de Științe (Idem, nr. 113, 22 mai 1945, p. 4 224).
} 
Zane s-a opus cât a putut excluderilor" ${ }^{\prime 54}$. Radicalismul procesului, aşa cum a încercat să-1 explice istoricul Lucian Boia, a ținut de tensiuni politice mai vechi între cei de dreapta și cei dintr-o stângă bine reprezentată în mediul universitar ieșean ${ }^{55}$.

În ordine cronologică, erau licențiați din serviciu prin Decizia nr. 115495 din 16 mai 1945 a Ministerului Educației Naționale, Grigore Scorpan, asistent Facultatea de Litere şi Filozofie, dr. Spiridon Poleacu, Radu Nimereanu şi dr. Nicolae David, asistenți la Facultatea de Medicină din Iași ${ }^{56}$. Urmau două decretelege care-i priveau pe profesorii titulari, conferențiari și asistenți definitivi. Încetau a mai face parte din corpul didactic al Universităţii „Cuza Vodă” din Iași: Ion Plăcințeanu, profesor titular și Florescu N. Alexandru, asistent definitiv la Facultatea de Științe; Gh. A.C. Cuza, Petre Dragomirescu, Gh. Drăgănescu, profesori titulari și Dumitru Gherasim, asistent definitiv la Facultatea de Drept; Dumitru Găzdaru, profesor titular la Facultatea de Litere și Filozofie; Ion Claudatus, Constantin Vasilescu, profesori titulari și Ioan Gheorghiu, agregat onorific și conferenţiar definitiv, toți la Facultatea de Medicină; Constantin Tomescu, profesor titular la Facultatea de Teologie ${ }^{57}$. Ultima etapă a epurării i-a vizat pe: Florin Sion, profesor titular la Facultatea de Drept, Radu Vulpe, profesor titular şi Emil Diaconescu, conferențiar la Facultatea de Litere și Filozofie, Lecca Morariu, profesor titular la Facultatea de Teologie și Timotei Cosciuc, șef de lucrări definitive la Facultatea de Ştiinț ${ }^{58}$.

Atmosfera tensionată generată de această acțiune în forță a avut efecte și asupra lui Theofil Simenschi a cărui numire ca profesor titular la catedra de Filologie comparată de la Facultatea de Litere și Filozofie din Iași, era anulată, rămânând pe mai departe, conferențiar, ataşat catedrei de limba și literatura latină ${ }^{59}$. În cazul lui A.C. Cuza, de la Facultatea de Drept și Gheorghe Pascu de la Facultatea de Litere şi Filozofie s-a apelat la decăderea lor din calitatea de profesori onorari ${ }^{60}$.

Un alt caz îl constituie eliminările din corpul universitar de la Universitatea din Cluj-Sibiu, unde au fost vizați: Onisifor Ghibu, profesor titular la Facultatea de

\footnotetext{
${ }^{54}$ Lucian Boia, op. cit., p. 254.

55 Personalizarea acestui proces de către Iorgu Iordan cumulată cu frica lui Andrei Oțetea de a nu cădea el însuşi între cei vizați sunt posibile explicații valorizate de istoricul Ovidiu Bozgan în Traiectorii universitare: De la stânga interbelică la comunism în coord. Lucian Boia, „Miturile comunismului românesc”, București, 1998, p. 154.

${ }^{56}$ Monitorul Oficial nr. 113, 22 mai 1945, p. 4226.

${ }^{57}$ Idem, nr. 115, 24 mai 1945, p. 4257.

${ }^{58}$ Idem, nr. 118, 28 mai 1945, p. 4377.

${ }^{59}$ Idem, nr. 115, 24 mai 1945, p. 4257.

${ }^{60}$ Idem, nr. 126, 6 iunie 1945, p. 4700.
} 
Litere și Filosofie, Traian Herseni, profesor titular și Al. Olteanu, asistent, amândoi de la Facultatea de Drept ${ }^{61}$.

Dacă în cazul lui Onisifor Ghibu, punctele sale de vedere naţionale și antisovietice nu erau tocmai agreate de noua putere politică care începea să se contureze $^{62}$, orientarea prolegionară a lui Traian Herseni fusese de notorietate, în fața unei societăți de status care nu-i lăsase o cale rezonabilă de ascensiune profesională.

Apărarea sa, într-o perioadă când cei vizați mai puteau trimite memorii a fost însă inutilă, dimpotrivă în urma unei plângeri a lui Florian Ștefănescu-Goangă este cercetat câteva luni, începând cu 26 februarie 1945, pentru acuzaţia de a fi contribuit la dezastrul țării și se pare că doar personalitățile publice care au depus în favoarea sa, 1-au scăpat de o posibilă condamnare.

Tot de la Universitatea din Cluj-Sibiu, sunt ,îndepărtați din funcție”, Titu Vasiliu, pentru șase luni, Iuliu Hațieganu, pe timp de trei luni, ambii profesori titulari la Facultatea de Medicină, acesta din urmă din motive care au ținut de vendete personale, și Grigore Popa, asistent la Facultatea de Litere și Filozofie pentru doi ani ${ }^{63}$.

Schimbarea rectorilor/prorectorilor, decanilor și prodecanilor a fost dorită din motive care țineau de imperativele etice ale perioadei, însă continua practica inaugurată de regimul antonescian de încălcare a autonomiei universitare prin recurgerea la numiri directe de către minister. Speranța revenirii la un regim democratic nu s-a materializat și în reinstaurarea deplinei autonomii universitare, situație ce transpare şi dintr-o ședință a Consiliului de Miniștri din 17 septembrie 1944 în care s-a analizat între altele înființarea unui comisariat al regiunilor eliberate din Transilvania, prilej cu care Iuliu Maniu a afirmat: „Noi am avut o Universitate la Cluj, care, din cauza evenimentelor, s-a mutat la Sibiu. La Universitatea din Cluj era obiceiul ca diferiții funcționari superiori - rectorul, prorectorul, decanul, prodecanul - să fie aleși dintre membri corpului profesoral al lor, în mod autonom. Erau aleși autonom din sânul Universității. A venit timpul dictatorial, care a desființat autonomia universităţilor și rectorul şi decanul au fost numiţi de Guvernul dictatorial. Ei au servit regimul. Acum mergem la Cluj. Trebuie să preluăm Universitatea. Acolo, la Universitate, ei au ținut o consfătuire și au făcut o comisie,

\footnotetext{
${ }^{61}$ Idem, nr. 169, 28 iulie 1945, p. 6465.

${ }^{62}$ Minodora-Maria Cioban Someșanu, Epurări în Universitatea Clujeană 1944-1958, București, Institutul pentru Studiul Totalitarismului, 2010, p. 80.

${ }^{63}$ Monitorul Oficial, nr. 169, 28 iulie 1945, p. 6465.
} 
care să preia Universitatea. Dar în această comisie au fost puși tot oamenii regimului trecut" ${ }^{\prime 64}$.

Conştient de slăbiciunea poziției sale în mediul universitar și cu scopul evident de a-și crea mijloace de control și de promovare a propriilor interese politice, guvernul procomunist condus de Petru Groza a emis periodic (anual) legi pentru modificarea art. 138 din Legea relativă la organizarea învățământului superior. Raportul nr. 114/1945 care însoțea Legea nr. 487 din 20 iunie 1945, întocmit de Ștefan Voitec, ministrul Educației Naționale este cât se poate de evident în acest sens: „În interesul bunului mers al învăţământului superior, este necesar să se prelungească până la 1 decembrie 1945, dreptul Ministerului Educației Naționale, de a putea numi direct organele de conducere din acest învăţământ, adică, pe rectori, prorectori, decani sau prodecani, pe un termen ce nu va depăși data de 1 Decembrie $1945^{\prime 65}$. Este foarte adevărat că în multe situații s-a recurs la reconfirmări ${ }^{66}$, însă posibilitatea revocării pe criterii arbitrare rămânea la îndemâna puterii politice.

Mutațiile petrecute în toamna anului 1944 au fost începute într-un context de reinstaurare a imperativelor etice după căderea dictaturii antonesciene, schimbarea de rectorilor, decanilor și a componenței Senatelor Universitare, prin încălcarea autonomiei acestora se va depărta de aceste deziderate inițiale, constituindu-se, nu de puține ori, în imixtiuni politice.

\section{Anul universitar 1945-1946. Impactul Decretului nr. 658 din 24 august 1946}

Anul universitar 1945-1946 nu a fost marcat de transformări radicale, dimpotrivă o anumită acalmie se așterne peste instituțiile de învățământ superior

\footnotetext{
${ }^{64}$ Marcel Dumitru Ciucă, op. cit., p. 151.

${ }^{65}$ Monitorul Oficial nr. 137, 20 iunie 1945, p. 5159.

${ }^{66}$ În mare parte, acestea au fost făcute publice pentru centrele universitare de la București și Cluj, prin două decrete-lege succesive. Pentru Universitatea din București erau fãcute precizări referitoare la Simion Stoilov, rector; Alexandru Rosetti, decan al Facultății de Litere şi Filozofie, Vasile Ispir, decan al Facultății de Teologie, Grigore T. Popa, decan al Facultății de Medicină și Alexandru Ciucă, decan al Facultății de Medicină Veterinară (Idem, nr. 152, 9 iulie 1945, p. 5 789). În ceea ce privește Universitatea din Cluj erau menționați Emil Petrovici, rector; G. Sofronie, decan al Facultății de Drept, Constantin Daicoviciu, decan al Facultății de Litere și Filozofie, M. Kernbach, decan al Facultății de Medicină din Cluj și Augustin Maior, decan al facultății de Științe (Idem, nr. 178, 8 august 1945, p. 6 877). La Iași, posibil, au avut loc cele mai multe reconfirmări, dintre noile mutații putând fi amintite, aducerea în prim-plan a lui Constantin Balmuș, ca decan al Facultății de Litere și Filozofie, deocamdată până la date de 1 decembrie 1945, precum și înlocuirea lui Alexandru Myller, rectorul Universității și a lui Ilie Popa, prorectorul acesteia, ambii demisionați, cu Andrei Oțetea, respectiv Constantin Mihul (Idem, nr. 176, 6 august 1945; Idem, nr. 263, 16 noiembrie 1945 , p. 10 027).
} 
unde mai mulți conferențiari sunt ridicați la poziția de profesori titulari, au loc nominalizări pentru conferințele vacante, în timp ce alții își vor face debutul în mediul universitar. $\mathrm{Cu}$ toate acestea, perioada la care ne referim nu a fost lipsită de o sincopă majoră.

Până la declanșarea Grevei Regale (21 august 1945-8 ianuarie 1946), transpunerea ocupării de conferințe prin publicarea decretelor regale se regăsește în cazul lui Jacques Byck pentru cea de Filologie română, ataşată catedrei de Limbă română și dialectele ei ${ }^{67}$, Aram Frenkian la cea de Limba și literatura elină cu specială privire la filozofia și științele elinice ${ }^{68}$ și I. Şiadbei la cea de Filologie romanică, toate la Facultatea de Litere și Filozofie a Universității din București ${ }^{69}$. De asemenea, Mihail Berza se titularizează ca profesor la catedra de Metodologie și istoriografie, genealogie și heraldică de la Școala de Arhivistică ${ }^{70}$, iar George Călinescu se transferă la cea de Istoria literaturii române moderne de la Facultatea de Litere și Filozofie din București ${ }^{71}$. Timp de peste patru luni, cât timp regele Mihai a întrerupt orice legături cu guvernul procomunist, condus de Petru Groza, și a refuzat să semneze orice act legal înaintat spre aprobare nu există publicate chemări pentru ocuparea de catedre.

După intrarea în guvern a reprezentanților P.N.Ț., Emil Hațieganu și P.N.L., Mihail Romniceanu (7 ianuarie 1946) și încetarea Grevei Regale vor fi numiți prin decrete regale: Ion Nestor, profesor titular la catedra de Arheologie și Preistorie ${ }^{72}$, Adelina Piatcovschi, asistentă cu titlu provizoriu la catedra de Limbă și literatură elenă de la Facultatea de Litere și Filozofie din București ${ }^{73}$, iar Lucrețiu Pătrășcanu intră în corpul universitarilor la catedra de Economie teoretică de la Facultatea de Drept $^{74}$.

Cele mai multe chemări la catedre și conferințe universitare au loc însă la Facultatea de Litere și Filozofie din Iaşi. Alexandru Dima va preda, începând cu data de 1 octombrie 1946, la conferința de „Estetică și critică literară" ${ }^{\prime 75}$, Neculai I. Popa devine profesorul titular al catedrei de Limbă și literatură franceză $\breve{a}^{76}$, iar Jean Livescu la cea de Limbă și literatură germană ${ }^{77}$. În sfârșit Teofil Simenschy ajunge

\footnotetext{
${ }^{67}$ Idem, nr. 161, 19 iulie 1945, p. 6144.

${ }^{68}$ Idem, nr. 167, 26 iulie 1945, pp. $6376-6377$.

${ }^{69}$ Idem, nr. 181, 11 august 1945, p. 7037.

${ }^{70}$ Idem, nr. 149, 5 iulie 1945, pp. 5 640-5 641.

${ }^{71}$ Idem, nr. 161, 19 iulie 1945, p. 6145.

${ }^{72}$ Idem, nr. 34, 9 februarie 1946, p. 988.

${ }^{73}$ Idem, nr. 145, 26 iunie 1946, p. 6588.

${ }^{74}$ Idem, nr. 119, 24 mai 1946, p. 5207.

${ }^{75}$ Idem, nr. 80, 3 aprilie 1946, p. 3441.

${ }^{76}$ Idem, nr. 83, 6 aprilie 1946, p. 3546.

${ }^{77}$ Idem, nr. 150, 2 iulie 1946, p. 6885.
} 
titularul catedrei de Filologie comparată ${ }^{78}$, urmat de Șerban Cioculescu, la cea de Istoria literaturii moderne ${ }^{79}$ și Dimitrie Ciurea la conferința de Istorie Universală ${ }^{80}$. Tabloul este întregit de Nicolae Grămadă care va ocupa catedra de Istoria Românilor de la Facultatea de Teologie din Suceava ${ }^{81}$.

Pe de altă parte, Gheorghe Zane se transferă de la Facultatea de Drept din Iași la catedra de Economie politică și raționalizare, aferentă cursurilor comune ale Politehnicii bucureștene ${ }^{82}$, solicitat fiind de ministrul Educației, Ștefan Voitec, cumva înaintea lui Iorgu Iordan pentru care însă, se înființează catedră de Lingvistică generală în locul celei vacante de Literatură comparată la Facultatea de Litere și Filozofie a Universităţii din București ${ }^{83}$.

La Cluj pot fi amintite: chemarea lui Alexandru Roșca (șef de lucrări la Institutul de Psihologie al Universității „Regele Ferdinand”) la conferința de Psihologie experimentală ${ }^{84}$, a lui Ioachim Crăciun la catedra de Istoriografie română

\footnotetext{
${ }^{78}$ Ibidem.

${ }^{79}$ Idem, nr. 167, 22 iulie 1946, p. 7648.

${ }^{80}$ Idem, nr. 161, 15 iulie 1946, p. 7389.

${ }^{81}$ Idem, nr. 150, 2 iulie 1946, p. 6886.

${ }^{82}$ Idem, nr. 37, 13 februarie 1946, p. 1 153; Referindu-se la intensificarea luptei politice din perioada premergătoare formării celui de-al doilea guvern Constantin Sănătescu, Gheorghe Zane reconstituie întreaga atmosferă, inclusiv turnura carierei sale profesionale: „un eveniment a survenit în toamna lui 1944 în cariera mea profesională. Am fost transferat la București, la catedra de economie politică și raționalizare de la Politehnică. Nu am solicitat această transferare, ci rectoratul Politehnicii a făcut în acest sens demersuri la minister. Catedra era liberă, prin îndepărtarea lui Mihail Manoilescu, nu avea cine să tină examenele. Ministrul Voitec mi-a cerut să le fac eu, Universitatea din Iași fiind închisă. După ținerea examenelor câțiva profesori, printre care rectorul N. Ciorănescu, mi-au cerut să fac și cursuri; apoi ei s-au ocupat de transferarea definitivă. Astfel am devenit, cu totul neaşteptat pentru mine, profesor la București, dar mult nu am rămas, căci în 1947 am fost revocat din motive politice. Corpul profesoral de la Politehnică era alcătuit din oameni distinși: Costin D. Nenițescu, Nicolae Ciorănescu, Nicolae Profiri, [...] Teodoru, Aurel Beleș, Elie Carafoli și mulți alții. Studenții - mulți întârziați, grăbiți să-și termine facultatea" (Gheorghe Zane, Memorii, Bucureşti, Editura Expert, 1997, p. 104).

${ }^{83}$ Legea nr. 159 pentru înființarea catedrei de Lingvistică generală la Facultatea de Litere și Filosofie din București în Monitorul Oficial nr. 61, 13 martie 1945, p. 209.

${ }^{84}$ Idem, nr. 66, 19 martie 1946, p. 2 450; Implicat încă din perioada celui de-al Doilea Război Mondial în acțiuni precum organizarea în cadrul Universității „Regele Ferdinand”, refugiată la Sibiu, a Uniunii Patrioților, ceea ce i-a atras inclusiv arestarea în procesul intentat, în principal, împotriva lui Barbu Zevedei (este eliberat din lipsă de probe), imediat după 23 august 1944 devine membru al Partidului Comunist, iar dintre sarcinile de partid cele mai importante poate fi amintită, organizarea și coordonarea celulei de partid din cadrul Universității (vezi pe larg, Camelia Zavarache, Geometria unei relații complexe: elite, modele ale modernizării statale și regimuri politice în România secolului XX în coord. Cristian Vasile, „Ne trebuie oameni!” Elite intelectuale și transformări istorice în România modernă și contemporană, Târgoviște, Editura Cetatea de Scaun, 2017, pp. 206-211).
} 
și științe auxiliare ${ }^{85}$, ambii la Facultatea de Litere și Filozofie precum și intrarea lui I.D. Sîrbu ca asistent la catedra de Istoria literaturii dramatice de la Conservatorul de muzică și artă dramatică ${ }^{86}$.

Cele câteva schimbări petrecute în anul universitar 1945/1946 aveau să se producă doar la nivelul conducerilor instituțiilor superioare din motive și cauze diferite.

Plecarea lui Simion Stoilov în fruntea reprezentanței diplomatice a României de la Paris i-a adus pe Alexandru Rosetti și Gheorghe Oprescu în poziția de delegați, primul ca rector al Universităţii din București începând cu data de 28 februarie $1946^{87}$, iar celălalt ca, decan al Facultății de Litere și Filozofie după 23 martie $1946^{88}$.

Starea de provizorat în privința numirilor de rectori/prorectori, decani și prodecani este perpetuată, astfel încât la 13 martie 1946 este emisă Legea nr. 157 pentru modificarea art. 138 din legea relativă la organizarea învățământului superior. Cum în urma aplicării ei, alături de Alexandru Rosetti și Gheorghe Oprescu, care sunt practic confirmați în funcțiile ce le dețineau, au mai fost numiți doar Gheorghe Popescu, ca decan al Facultăţii de Farmacie și Vasile Rășcanu la Facultatea de Medicină, putem conchide că la celelalte facultăți nu s-au produs revocări din funcții ${ }^{89}$.

Mutația esențială în privinţa chemărilor la catedră și a anulării altor principii de autonomie universitară avea să se materializeze prin Decretul-Lege nr. 658 din 24 august 1946. Până la această dată numirile din învățământul superior funcționaseră cu o integritate rezonabilă, revenirea la catedră a lui Simion Stoilov sau numirea lui Lucrețiu Pătrășcanu, acesta din urmă făă activitate pedagogică, constituindu-se, mai degrabă, în situații excepționale care nu pot fi generalizate.

Decretul-Lege nr. 658 din 24 august 1946 pentru modificarea unor dispoziţii din Legea relativă la organizarea învățământului superior a extins și adâncit cu mult mai mult sfera încălcării autonomiei universitare. În termeni unidirecționali, aceasta a condus la configurarea a două poziționări extreme: una a refuzului constrângerilor şi intruziunii politicului în Universități, cunoscute fiind opiniile exprimate la Iași de profesorii Petru Caraman, Dan Bădăău ${ }^{90}$ sau memoriul întocmit la București de

\footnotetext{
${ }^{85}$ Idem, nr. 161 din 15 iulie 1946, p. 7391.

${ }^{86}$ Idem, nr. 182 din 8 august 1946, p. 8550.

${ }^{87}$ Idem, nr. 50 din 28 februarie 1946, p. 1587.

${ }^{88}$ Idem, nr. 70, 23 martie 1946, p. 2683.

${ }^{89}$ Idem, nr. 127, 4 iunie 1946, pp. 5 661-5 662.

90 Dănuț Doboș, Reforma învățământului Decretul 175/1948 în Arhivele Totalitarismului, Anul III, nr. 3/1995, București, Editura Academiei Române, 1995, p. 201. În ședințele Senatului Universității ieșene, încă din anii 1945-1946 au existat voci care s-au ridicat
} 
Grigore T. Popa, decanul Facultății de Medicină $\breve{91}^{91}$ și cealaltă a alinierii rectorilor (Constantin Balmuș și Alexandru Rosetti) la poziția guvernului.

Numirea directă a conducerilor instituțiilor de învățământ superior, începând cu toamna anului 1944, prin nesocotirea aceluiași principiu al autonomiei universitare, a fost mai puțin vizibilă, deoarece era un efect al dorinței de distanțare și diferențiere față de regimul Antonescu, iar, pe de altă parte, acea primă serie de universitari puși sau reconfirmați în fruntea lor era formată din nume reprezentative, ce aveau la bază o substanțială recunoaștere științifică.

În principal, două erau dispozițiile nou-introduse prin Decretul-Lege nr. 658 din 24 august 1946: înlocuirea Consiliului Universitar cu un Consiliul Consultativ, numit direct de ministru ${ }^{92}$, cu atribuții mult sporite, și introducerea art. 64 bis referitor la normele de aplicare în cazul chemărilor la catedră, articol care crea posibilitatea intrării în corpul profesoral fără respectarea tuturor criteriilor meritocratice ${ }^{93}$.

Crearea unei legături indestructibile între puterea de decizie a Consiliului Consultativ și chemările la catedră, mai ales pe baza articolului 64 bis, s-a realizat prin prevederile art. 109, în sensul în care „catedrele și conferințele se puteau transfera, transforma, desființa sau înființa motivat, numai prin lege, în urma cererii forurilor competente universitare, sau tot prin lege la propunerea Ministerului în

împotriva încălcării autonomiei universitare și a politizării sub pretextul defascizării (Dan Lazăr, Situația Universității din Iași în primii ani postbelici (1945-1950). Considerații, în Stela Cheptea, Silviu B. Moldovan (coord.), Consecințe ale celui de al Doilea Război Mondial în spațiul românesc, București, Editura Eikon, 2017, pp. 216-217.

${ }^{91}$ Ovidiu Bozgan, L'Université de Bucarest à l'époque du régime communiste în „Arhivele Totalitarismului”, vol. IV-V, nr. 13-14, 1996-1997, p. 231. Numit, atât de frumos, de Radu Iftimovici ,un filozof al biologiei”, Grigore T. Popa s-a angajat imediat după 23 august 1944 în eforturile de reinstaurare a vieții democratice din România. Începe să fie perceput ca oponent al noii forțe politice comuniste care începea să se contureze tot mai puternic, odată cu demisia din ARLUS și contestarea paradigmei ideologice sovietice căreia îi opune modele științifice americane și engleze. Despre destituirea sa din funcția de decan al Facultății de Medicină aflăm într-un mod indirect, dintr-o decizie ministerială publicată pe 2 decembrie 1946 privind delegarea profesorului N.G. Lupu în respectiva funcție (M.O., nr. 279, 2 decembrie 1946, p. 12 515). În medalionul biografic pe care i-l dedică după mai mulți ani, Vasile Igna lansează ipoteza că susținerea conferinței intitulată Morala creștină și timpurile actuale (subintitulată „Mai este astăzi posibilă credința în Isus Cristos?”) la 15 aprilie 1947 în fața unei săli arhipline la Ateneul Român îi va atrage o intensificare a supravegherii de către Siguranță. Exclus din Universitate, reușește să trăiască aproape un an în clandestinitate. Se stinge însă din viață la 18 iulie 1949 (Vasile Igna, Subteranele memoriei Pagini din Rezistența Culturii 1944-1954, București, Editura Universal Dalsi, 2001, pp. 43-44).

${ }_{92}$ Monitorul Oficial, nr. 195, 24 august 1946, p. 9193.

${ }^{93}$ Dănuț Doboș, op. cit., p. 201. 
urma avizului Consiliului Consultativ al Învățământului Superior. Aceleași norme trebuiau respectate și la schimbarea titulaturii catedrelor și conferințelor" ${ }^{\prime \prime}$.

Fenomenul creării de noi catedre la propunerea Ministerului, cu avizul respectivului Consiliu a îmbrăcat diverse forme în anul universitar 1946-1947. Printre catedrele nou înființate, susceptibile a avea contingență politică le putem aminti pe cele de Istorie Economicăa ${ }^{95}$, Economie Politică şi Socială, de la Facultatea de Litere și Filozofie din București și de Metodologie și Sociologie, de la Facultatea de Drept, catedre ocupate apoi de Andrei Oțetea, Bellu Zilber și Marius Manolescu.

O altă formă de ridicare facilă la statutul de profesor universitar a constituito dublarea catedrelor universitare prin recurgearea la separarea materiilor de studiu predate de către un profesor titular. Este cazul catedrei și conferinței de catehetică și omiletică de la Facultatea de Teologie din București divizată în: catedra de catehetică, catedra de omiletică și exerciții de predică și conferința de omiletică patristică $^{96}$. O situaţie cu implicaţii dintre cele mai dramatice s-a petrecut la Facultatea de Medicină din București, unde catedra de chimie a fost despărțită în două, pentru a face loc lui Simion Oeriu ${ }^{97}$. Am identificat o notă a Siguranței din 13 februarie 1947, întocmită cu puțin timp, după finalul tragic al evenimentelor, notă pe care o vom reda în integralitatea sa: „În rândurile studenților mediciniști continuă

\footnotetext{
${ }^{94}$ Monitorul Oficial nr. 195, 24 august 1946, p. 9194.

${ }^{95}$ Inițial, Legea 872 înființa Catedra de Clinica a-V-a medicală la Facultatea de Medicină București și Catedra de Istorie Socială la Facultatea de Filozofie și Litere din București. Decretul nr. 48 din 17 ianuarie 1947 de ocupare prin transfer a acestei din urmă catedre de către Andrei Oțetea, păstra titulatura menționată. La 11 februarie 1947 intervenea o rectificare, în sensul în care acesta apare drept profesor al catedrei de Istorie Economică (Idem, nr. 259, 7 noiembrie 1946, p. 11 707; Idem, nr. 10, 17 ianuarie 1947, p. 243; Idem, nr. 34, 11 februarie 1947, p. 1 046). Angajat politic, devenit vicepreședinte al Partidului Național Popular, pro-comunist, mutarea la Universitatea din București a implicat în cazul său și încadrarea ca prorector al acesteia, în locul lui Eugen Angelescu, forțat, probabil, să se retragă din respectiva funcție (Idem, nr. 30, 6 februarie 1947, p. 903). In schimb, la Universitatea din Iași este delegat ca rector Leon Baliff (Idem, nr. 26, 1 februarie 1947, p. 763).

${ }^{96}$ Decretul-lege nr. 3368 pentru înființarea și transformarea unor catedre și conferințe din învățământul superior în Monitorul Ofícial nr. 278 din 30 noiembrie 1946, p. 12 405. În privința ocupării acestor posturi, date precise avem despre Dumitru Fecioru, membru al Uniunii Preoților Democrați (formațiune procomunistă), ajuns, în primăvara anului 1947, conferențiar definitiv la conferința de Omiletică patristică la Facultatea de Teologie din București (Idem, nr. 94, 26 aprilie 1947, p. 3 275).

${ }^{97}$ Legea nr. 925 pentru scindarea catedrei de chimie generală medicală și chimie biologică de la Facultatea de Medicină București și Decretul-lege nr. 3640 pentru numirea domnului dr. Simion Oeriu, profesor titular la catedra de „Chimie biologică” de la Facultatea de Medicină din București în baza articolului 64 bis din Legea relativă la organizarea învățământului superior (Idem, nr. 270, 21 noiembrie 1946, p. 12 079; Idem, nr. 299, 30 decembrie 1946, p. 13 209).
} 
încă să domnească sentimentul de indignare provocat de cazul Vintilă Ciocâlteu Simion Oeriu. Această indignare a fost întărită când, în ultimul timp, s-a aflat că Oeriu reuşise să smulgă lui Ciocâlteu o scrisoare prin care acesta se declara de acord cu scindarea catedrei de Chimie. În afară de aceasta studenții au aflat că Oeriu a manevrat în așa fel, încât o mare parte din personalul laboratorului de chimie a trecut de partea sa încă înainte de moartea lui Vintilă Ciocâlteu [în urma unui schimb violent de cuvinte cu Simion Oeriu și după întocmirea unui memoriu către rectorat, profesorul Vintilă Ciocâlteu a suferit un prim șoc și anume ridicarea tensiunii și declanşarea unei hemoragii cerebrale $n . n$.]. El a promis că va da acestui personal un plus de indemnizație în scopul de a-l câștiga de partea sa.

Astfel, numai personalul feminin a rămas credincios lui Ciocâlteu. În aceste împrejurări o delegație de studenți s-a prezentat la prof. Gr. T. Popa, înmânându-i un buchet de flori și o troiţă sculptată în lemn, drept recunoștință pentru atitudinea arătată în cazul Ciocâlteu. Fostul decan al facultății n-a putut să răspundă delegației de studenți fiind copleșit de lacrimi. Această stare de spirit care domnește la Facultatea de Medicină, face imposibilă deschiderea cursului profesorului Oeriu" ${ }^{\prime \prime}$. În fața ostilităţii studenților și pentru a evita orice fel de tulburări, autorităţile numesc doi suplinitori la respectiva catedră (dr. Isăcescu la anul I și dr. Niţulescu la anul II $)^{99}$.

Instituirea acestui nou cadru legal a făcut posibilă, de asemenea, prin articolul 64 bis, titularizarea sau promovarea la nivel de profesor, pe acele catedre vacante, deja existente. În cazul Facultății de Teologie din Suceava pot fi amintiți în acest sens: Gheorghe Arghiropol, la catedra de „Drept Bisericesc"100, N.I. Nicolaescu, la cea de „Exegeza Noului Testament, Ermineutica Biblică”101 și Petru

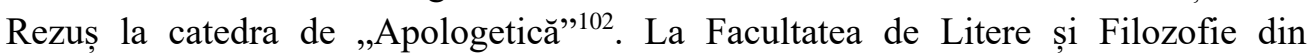
București devin profesori titulari Alexandru Graur, la catedra de „Limbă și literatură latină”, catedră unde îl înlocuise pe Nicolae Herescu încă din ianuarie $1945^{103}$ și Anton Dumitriu, la cea de „Introducere în filozofie, logică și istoria filozofiei vechi și medievale" ${ }^{104}$, urmați de Nicolae Balca, nominalizat la conferința de „Filozofie" ${ }^{105}$. De asemenea, la numai un an de la intrarea în rândul conferențiarilor,

\footnotetext{
${ }^{98}$ ACNSAS, fond Documentar, dosar nr. 12 823, vol. 2, f. 188.

${ }^{99}$ Ibidem, f. 135.

${ }^{100}$ Monitorul Oficial, nr. 277, 29 noiembrie 1946, pp. 12 360- 12361.

${ }^{101}$ Idem, nr. 17, 21 ianuarie 1947, p. 493.

102 Idem, nr. 78, 3 aprilie 1947, p. 2695.

${ }^{103}$ Florin Manolescu, Enciclopedia exilului literar românesc. 1945-1989, București, Editura Compania, 2003, p. 373; Monitorul Oficial nr. 297, 23 decembrie 1946, p. 13135.

${ }^{104}$ Idem, nr. 281, 4 decembrie 1946, p. 12559.

105 Idem, nr. 94, 26 aprilie 1947, p. 3276.
} 
Alexandru Roșca era ridicat la rangul de profesor titular la catedra de „Psihologie Socială”, din cadrul Facultății de Litere și Filozofie din Cluj ${ }^{106}$.

Situația lui Alexandru Graur este însă una particulară deoarece o nedreptate care prefigura o multitudine de măsuri și practici anti-Semite ${ }^{107}$ este reparată mai târziu, nu făă acordul său, în contextul creării acestei situații excepționale de intrare în învăţământul superior ${ }^{108}$.

Așadar, făcute înainte de prima mare restructurare intervenită în toamna anului 1947, aceste mutații, generatoare de momente dintre cele mai dramatice, nu au avut o pondere însemnată în modificarea componenței corpului universitar ceea ce ne face să conchidem că au constituit, mai degrabă, o măsură de natură a-i transfera sau fixa în posturi universitare, păstrând aparențele unei firave legalități, pe cei apropiați comuniștilor sau pe tovarășii lor de drum.

Ar fi, de asemenea, incorect să nu precizăm faptul că apelul la articolul 64 bis în cazurile sus-amintite nu a anulat recrutarea şi promovarea în baza prevederilor legale statuate în 1942 de Legea relativă la organizarea învățământului superior. Pentru anul universitar 1946-1947, exemplele de promovare cu îndeplinirea tuturor cerințelor legale sunt nenumărate: Marius Nasta a fost înălțat la rangul de profesor titular al catedrei de „Ftiziologie” de la Facultatea de medicină din București ${ }^{109}$, Tudor Drăganu la cea de „Drept constituţional” de la Facultatea de Drept din Cluj ${ }^{110}$, Dumitru Stăniloae ocupă din ianuarie 1947, catedra de „Teologie ascetică și mistică”

\footnotetext{
${ }^{106}$ Idem, nr. 34, 12 februarie 1947, p. 1079.

107 Implicat în gazetăria de factură procomunistă, George Călinescu furnizează câteva amănunte semnificative în privința acestui episod: ,acum vreo șapte ani, când regimul nu era oficial antisemit, s-a prezentat să candideze la o conferință de Limbă elină, de la Facultatea de litere din Iași, Alexandru Graur, care este un savant unanim recunoscut în lumea ştiințifică. Toți profesorii serioși, preocupați numai de interesul didactic al Facultății îl voiau, dar concursul nu s-a putut ține căci a dispărut conferința din buget, nu prin hotărârea Parlamentului cum era legal, ci printr-o eroare de zețărie, la «Monitorul Oficial»" (George Călinescu, Evreii, în „Tribuna Poporului”, An I, nr. 10, 24 septembrie 1944).

${ }^{108}$ Evident $\mathrm{o}$ atare poziționare a sa nu avea cum să nu genereze reacții contradictorii, însă destinul său este simptomatic pentru perioada pe care o traversează, radicalismul extremei drepte din anii 1930 îl îndreaptă și radicalizează spre stânga comunistă, în timp ce, ajuns director adjunct al Institutului de Lingvistică în 1949, formația sa profesională îl aduce în dezacord flagrant cu echipa ideologică a Agitprop-ului (vezi pe larg, Cristian Vasile, Schița unui portret: cazul Alexandru Graur - reputat lingvist, socialist, comunist, „dușman al poporului" în Caietele CNSAS, Anul X, nr. 2 (20)/2017, pp. 55-82).

${ }^{109}$ Monitorul Oficial, nr. 232, 7 octombrie 1946, p. 10809.

${ }^{110}$ Idem, nr. 235, 10 octombrie 1946, p. 10925.
} 
de la Facultatea de Teologie din București ${ }^{111}$, iar Dimitrie Todoranu cea de „Pedagogie și Istoria Pedagogiei” de la Facultatea de Litere şi Filozofie din Cluj ${ }^{112}$.

Un palier mai jos, Dimitrie Macrea a fost numit conferențiar definitiv la conferința de „Limba română și dialectele ei”, de la Facultatea de Litere și Filozofie din Cluj ${ }^{113}$, Tudor Popescu, la cea de „Drept Civil”114, urmați de Ion Rosetti Bălănescu la conferința de „Enciclopedia Dreptului”, amândouă la Facultatea de Drept din București ${ }^{115}$.

În aceeași perioadă, Edgar Papu ${ }^{116}$ și Petre Botezatu ${ }^{117}$ au fost definitivați în posturile de asistenți la Facultatea de Litere și Filozofie din București, respectiv Iași (catedra de psihologie). Apoi o serie întreagă de tineri intră asistenţi cu titlu provizoriu: Rodica Ciocan la Institutul de Studii și Cercetări Balcanice ${ }^{118}$, Eleonora Costescu, pe lângă catedra de Istoria Artei ${ }^{119}$ de la Facultatea de Litere și Filozofie din București, Tancred Bănățeanu la Muzeul Etnografic ${ }^{120}$ de pe lângă Facultatea de Litere și Filozofie din Cluj iar Virgil Godeanu pe lângă catedra de Teologie Dogmatică ${ }^{121}$ de la Facultatea de Teologie București.

Din această perspectivă, Decretul-Lege nr. 658 din 24 august 1946 pentru modificarea unor dispoziții din Legea relativă la organizarea învățământului superior a fost o primă etapă dintr-o evoluție socială și instituțională mergând spre controlul total al învățământului universitar. În cadrul acesteia au mai coexistat ascensiuni profesionale în baza unui curriculum universitar incontestabil cu cele excepționale făcute în baza articolelor nou introduse. Momentul de ruptură avea să se producă începând cu toamna anului 1947, când vor fi operate masive disponibilizări, sub pretextul necesității economiilor bugetare.

\section{Forme de îndepărtare a profesorilor universitari din învățământul superior românesc 1947-1948}

Perioada ce urmează semnării Tratatului de Pace cu Puterile Aliate, la Paris, în data de 10 februarie 1947, a fost marcată de pregătirea condițiilor de preluare

\footnotetext{
${ }^{111}$ Idem, nr. 10, 10 ianuarie 1947, p. 243.

${ }^{112}$ Idem, nr. 35, 12 februarie 1947, p. 1079.

${ }^{113}$ Idem, nr. 65, 19 martie 1947, p. 2033.

114 Ibidem.

${ }^{115}$ Idem, nr. 73, 28 martie 1947, p. 2323.

${ }^{116}$ Idem, nr. 272, 23 noiembrie 1946, p. 12137.

${ }^{117}$ Idem, nr. 283, 6 decembrie 1946, p. 12607.

${ }^{118}$ Idem, nr. 279, 2 decembrie 1946, p. 12515.

${ }^{119}$ Idem, nr. 27, 3 februarie 1947, p. 783.

${ }^{120}$ Idem, nr. 75, 31 martie 1947, p. 2441.

${ }^{121}$ Idem, nr. 76, 1 aprilie 1947, p. 2623.
} 
efectivă a tuturor structurilor politice, economice și instituționale. Mai nimic din evenimentele petrecute în 1947 nu se derulează întâmplător și circumstanțial. Adoptarea de noi legi circumscrise etatizării economice, eliminarea celui mai puternic partid de opoziție și înlăturarea monarhiei au fost doar câteva dintre cele mai radicale măsuri ale acestui proces.

Debutul noului an fiscal a fost pretextul ca, începând cu 1 mai 1947, să fie pus în practică un plan bine stabilit de accelerare a preluării controlului întregului aparat instituțional și administrativ printr-o vastă acțiune de licențieri. Articolul 55 din Legea nr. 139 pentru evaluarea şi perceperea veniturilor şi fixarea cheltuielilor statului pe exercițiul financiar 1947/1948 prevedea într-un mod cât se poate de evident: „prin Jurnal al Consiliului de Miniștri se vor fixa modalitățile ca, până la data de 1 iunie 1947, totalul cheltuielilor de salariu din bugetele ministerelor şi instituțiilor autonome să fie redus cu 30\% față de creditele înscrise în Bugetul de Stat" ${ }^{\prime 22}$.

Emanat de la aceeași autoritate, un alt Jurnal al Consiliului de Miniștri, din 23 mai 1947, fixa condițiile licențierilor din serviciu. Acesta din urmă ne indică două direcții de acțiune în „raționalizarea” învățământului superior. În primul rând posturile vacante nu mai puteau fi ocupate până la data de 31 mai 1948 decât prin înaintări și chemări din cadrul personalului deja existent în respectiva instituție. În al doilea rând, criteriile de licențiere impuse erau un amestec de prescripții interdicționale financiare uzitate și în trecut, cu standarde ce țineau de introducerea, de abia perceptibilă a „purității de clasă” în rândul corpurilor profesionale. Erau astfel supuși licențierii: „,ei pentru care nu există post în buget și sunt plătiţi din fonduri globale sau fonduri cu denumiri asemănătoare; cei cărora li s-au desfiinţat funcțiile sau posturile și nu au fost încadrați în altă funcție sau post; cei care, după 23 august 1944, au suferit pedeapsa disciplinară a suspendării din serviciu pe timp limitat sau o pedeapsă mai mare; cei care prin randament sau moralitate scăzută ingreunează mersul serviciului sau aduc atingere prestigiului corpului din care fac parte [subl.n.]; cei care nu au atribuții efective de serviciu" ${ }^{\prime 23}$.

Considerând că schimbarea corpului profesoral universitar a presupus două etape, una de eliminare a celor care nu corespundeau criteriilor politice ale Partidului Comunist și cealaltă de aducere la catedră a celor selecționați în funcție de îndeplinirea anumitor standarde sociale și evident politice, interesul special pentru înlăturarea primei categorii a stat la baza instituirii a două comisii: una compusă din profesorul Traian Săvulescu, ministru subsecretar de stat, profesorul Miron Nicolescu, ministru subsecretar de stat, C. Tegăneanu, ministru subsecretar de stat,

${ }^{122}$ Idem, nr. 98,1 mai 1947, p. 3434.

${ }^{123}$ Idem, nr. 115, 23 mai 1947, pp. 4 083-4 086. 
profesorii Constantin Daicoviciu și Petre Constantinescu-Iași, acesta din urmă președintele Uniunii Sindicatelor Corpului Didactic Secundar și Universitar, pentru raționalizarea întregului învăţământ superior ${ }^{124}$ și una alcătuită din profesorii Andrei Oțetea, I.V. Nicolescu, delegați ai Ministerului Educaţiei și profesorul N. Bărbulescu, delegat al Uniunii Sindicatelor Corpului Didactic Secundar și Universitar, pentru cercetarea situației tuturor membrilor corpului didactic din învățământul superior ${ }^{125}$. Cele două comisii se vor contopi la 16 iulie 1947 într-o singură comisie interministerialăă ${ }^{126}$, însă trecând peste acestă informație pur factuală, trebuie precizat că excesiva epurare a învățământului superior sub motivații financiare nu poate fi separată de reacțiile mediului universitar, care fără a avea o semnificație importantă, prezintă particularitatea că, de data aceasta, ele provin din partea universitarilor apropiați P.C.R. sau a aliaților social-democrați.

Dacă pentru Universitatea din Iași pot fi invocate pozițiile rectorului Leon Baliff și ale lui Vasile Rășcanu, decanul Facultăţii de Medicină ${ }^{127}$, în cadrul Comisiei Interministeriale pentru comprimări se pare că cea mai dură poziție a fost cea a prof. Traian Săvulescu. Într-o notă din dosarul de cadre al acestuia s-au păstrat câteva informații prețioase referitoare la problema comprimărilor:

„a. - Când s-a pus [a fost supus aprobării n.n.] în Consiliul de Miniștri, Jurnalul Comisiei Interministeriale pentru comprimări, deși a fost solicitat de tovarășul Daicoviciu, prof. Traian Săvulescu n-a vrut să ia deloc cuvântul, lăsând ca toate discuțiile să fie suportate de tov. Constantin Daicoviciu.

b. - În ședinţa comisiei interministeriale la care a participat (singura de altfel la care a asistat) a acceptat cu oarecare rezerve unele comprimări, cerând însă să-i arătăm ce înțelegem prin «reacționar», ce acte avem contra lui Gh. Brătianu și mai ales că nu putem scoate un om numai pentru faptul că este manist (deși cei mai mulți reacționari au nu numai atitudinea politică care-i fac epurabili, ci și multe alte acțiuni și atitudini dăunătoare democrației).

c. - Când a fost vorba de comprimarea preotului profesor Nae Popescu, membru al Academiei și profesor la Teologie, s-a opus complet, deși a recunoscut că este o nulitate și o lichea, amenințând că el își dă demisia de la Academie. În fața argumentației strânse a tovarășului Petre Constantinescu-Iași, a trebuit să recunoască că nu are dreptate, totuși n-a cedat.

d. - S-a opus complet ca să se facă epurări la Facultatea de Agronomie (doar unu sau doi), deși recunoștea că majoritatea nu au nici nivel profesional, nici nu sunt

\footnotetext{
${ }^{124}$ Idem, nr. 118, 27 mai 1947, p. 4197.

${ }^{125}$ Idem, nr. 122, 31 mai 1947, p. 4363.

${ }^{126}$ Idem, nr. 160, 16 iulie 1947, p. 6091.

${ }^{127}$ Mariana Momanu, Educație și ideologie. O analiză pedagogică a sistemului totalitar comunist, Iași, Editura Universității „Al. I. Cuza”, 2005, p. 182.
} 
democrați, pe motiv că nu are cu cine-i înlocui. A cerut și părerea „fiului lui sufletesc", care însă 1-a dezavuat și a arătat cu cine ar putea fi înlocuitorii celor comprimabili. Pe această chestiune a fost intransigent: amenințând că-și dă demisia și din învățământ și acoperind cu ocări pe tovarășii Constantinescu, Neagu și alții din celula de partid a Universităţii (grupa Agronomie).

e. - La Politehnică şi Arhitectură s-a opus la epurarea profesorului Ciorănescu și a altora cu care este prieten. Ne va fi greu să lucrăm cu el și să-l facem să ne sprijine. Social-Democrații au simțit acest lucru și-l exploatează în felul următor:

f. - Grupa de partid de la Agronomie și cea din Minister a avut năstruşnica idee ca să trimită și lui Voitec caracterizările pe care le-au făcut asupra tuturor profesorilor şi conferențiarilor de la Agronomie. Despre prof. Traian Săvulescu au scris următoarele: «vechi democrat, savant, excelent profesor, foarte sever și cinstit, însă poate fi derutat prin informații false». Voitec a primit acele caracterizări și le speculează la maximum. La Consiliul de Miniştri 1-a tras deoparte pe Prof. Traian Săvulescu și i-a vorbit foarte indignat despre felul cum este el caracterizat de comuniștii de la agronomie. Prof. Traian Săvulescu este foarte afectat de acest lucru și gata să nu ne facă multe greutăți nouă. Voitec și social-democrații caută să și-1 apropie. (Pe linia noastră s-a dispus luarea de măsuri contra tovarășilor de la Agronomie care au făcut această prostie; pe linia organizatorică vor fi chemați și sancționați)" ${ }^{\prime 28}$.

Dificultăţile întâlnite din chiar interiorul sistemului, în măsura în care acestea nu au avut un impact foarte puternic ne arată slaba rezistență a societății în fața constrângerilor politice. Procesul de masivă epurare desfășurat în toamna anului 1947 poate fi considerat începutul înlocuirii unui corp profesoral universitar cu un altul puternic politizat și controlat de stat. Faptul că legiuitorul e obligat să recurgă la decizii cu un conținut motivațional diferit, dar subordonate aceluiaşi scop, de a curăți terenul de persoanele indezirabile unui regim pe cale de a se consolida, arată grija deosebită de a se asigura că respectivele măsuri vor fi urmate într-un mod riguros.

Alături de două decizii privind suprimarea temporară a prevederilor bugetare pentru posturile de personal didactic ajutător ${ }^{129}$, respectiv a mai multor

${ }^{128}$ Gheorghe Buzatu și Mircea Chirițoiu (editori), Agresiunea comunismului în România. Documente din Arhivele Secrete: 1944-1989, vol. II, București, Editura Paideia, 1998, pp. 161-162.

${ }^{129}$ Monitorul Oficial, nr. 229, 4 octombrie 1947, pp. 8 938-8 941. 
catedre și conferințe ${ }^{130}$, au fost puși în retragere din oficiu, pentru a-și aranja drepturile la pensie mai mulți profesori universitari ${ }^{131}$.

La Universitatea din București, Facultatea de Teologie, lista se deschide cu Ion Savin, profesor titular la catedra de Apologetică, pentru ca apoi să-i succeadă Şerban Ionescu, catedra de Teologie morală, și Toma Bulat la cea de Istoria Bisericii Universale. De la Facultatea de Drept erau nevoiți să se pensioneze: Alexandru Oteteleșanu, profesor titular la Catedra de Drept comparat cu aplicații la dreptul privat și D. Arion, la conferința de Istoria Dreptului Românesc. Facultatea de Litere și Filosofie urma să fie lipsită de aportul universitarilor: Ștefan Ciobanu, profesor titular la catedra de Istoria literaturii române vechi, I.D. Ștefănescu, de la cea de Istoria artelor, D. Marmeliuc, de la catedra de Limba și literatura elină, Vasile Grecu, de la cea de Bizantinologie, Marin Lișcu, de la catedra de Limbă Latină, Teofil Sauciuc Săveanu, profesor titular la catedra de Istorie Antică şi Epigrafie și N.A. Constantinescu, de la Conferința de Științe auxiliare ale Istorie.

Universitatea din Cluj mergea pe aproximativ aceeaşi ordine a nominalizărilor. De la Facultatea de Drept plecau doi prestigioși profesori și anume: Petre Poruțiu, de la catedra de Drept Comercial și Traian Pop, de la cea de Drept penal și procedură penală. Îi succeda Facultatea de Litere și Filosofie de unde erau înlăturați: Constantin Sudețeanu, de la Sociologie și Etică, Gheorghe Giuglea, profesor titular la catedra de Filologie romanică, Emil Panaitescu de la cea de Istorie Antică și epigrafie, Romulus Cândea de la Istoria Universală, Romul Vuia de la catedra de Etnografie și folclor și Silviu Dragomir, profesor titular la catedra de Istorie Sud-Est Europeană. Din cadrul Facultății de Litere şi Filozofie a Universităţii Bolyai, părăsea catedra de Istoria literaturi maghiare, Ludovic Gyorgy. La Universitatea din Iaşi, pensionările din oficiu erau ceva mai reduse. Erau pensionaţi: Valeriu Iordăchescu, profesor de Teologie Morală și Alexandru Ieșan, de la catedra de Filosofie și Pedagogie, amândoi de la Facultatea de Teologie și Alexandru Boldur, profesor de Istoria Românilor la Facultatea de Litere și Filozofie.

Pentru a nu lăsa loc de interpretări, deoarece Legea relativă la organizarea învățământului superior permitea prelungirea cu încă doi ani a activității profesorilor universitari, cu aprobarea Senatelor Universitare, este emisă o decizie separată și pentru cei care împliniseră deja limita de vârstă. Au fost astfel puși în retragere de la Universitatea din București: Nicolae Popescu, profesor la catedra de Istoria Bisericii Românești și Grigore Pișculescu (Gala Galaction), de la cea de Exegeza Vechiului Testament şi Limbă ebraică; Anibal Teodorescu, specialist în Drept Administrativ, apoi de la Facultatea de Litere și Filosofie: G.G. Antonescu, afirmat în domeniul

\footnotetext{
${ }^{130}$ Ibidem, pp. $8941-8943$.

${ }^{131}$ Ibidem, pp. $8948-8949$.
} 
Pedagogiei și Istoriei pedagogiei, Ilie Bacinschi, în cel al Filologiei romanice, Dimitrie Gusti, fondatorul Sociologiei româneşti şi Gheorghe Oprescu, pe care această decizie îl găsește profesor titular la Catedra de Istoria artelor. De la Universitatea din Iași era nevoit să-şi încheie activitatea profesorală, Cicerone Iordăchescu, (Istoria Bisericii Universale), iar de la Universitatea din Cluj, Camil Negrea de la catedra de Drept Civil și Florian Ștefănescu-Goangă, de la cea de Psihologie ${ }^{132}$. Cum nimic nu este lăsat la voia întâmplării, toate catedrele care au fost ocupate de cei pensionați sunt suprimate temporar, respectiv definitiv, prin alte două decizii succesive ale ministrului Educației, Ștefan Voitec ${ }^{133}$.

Dorinţa statului de a-și instaura controlul atât în privința corpului profesoral, cât și în ceea ce privește conținutul materiilor predate, mai ales în ceea ce reprezenta latura sa umanistă, se manifestă și mai explicit prin Decizia nr. 266.979 publicată în 14 octombrie 1947 de comprimare și raționalizare a mai multor persoane și catedre $^{134}$.

La Universitatea din București, Facultatea de Drept au loc substanțiale reduceri dintre care amintim: Gheorghe Fotino, de la catedra de Istoria dreptului românesc, Virgil Veniamin, de la Filosofia dreptului, N.I. Fințescu, de la cea de Drept comercial sau Erwin Antonescu, de la conferința de Drept internațional privat. În ordinea indezirabilității urma Facultatea de Teologie, de unde sunt comprimate „persoana și postul” sau mai precis Haralambie Cojocaru, asistent suplinitor la Exegeza Noului Testament și Ioan Lăncrănjan, asistent definitiv de Teologie morală.

La Facultatea de Litere și Filosofie are loc o adevărată „hecatombă”, pentru a prelua sintagma istoricului Lucian Boia, care conexată apoi cu penalizări politice sau imposibilitatea de a mai activa, măcar într-un domeniu înrudit, a condus atât la dispariţia cât și la stoparea evoluției profesionale a mai multor universitari. Sunt comprimați: Gheorghe Brătianu de la catedra de Istorie universală (doar persoana, nu și catedra) Gheorghe Nandriș și P. Cancel de la cea de Slavistică (limbile bulgară și sârbă), Dragoș Protopopescu - Limba și literatura engleză, Gheorghe Narly Pedagogie și Istoria pedagogiei, C.I. Petrescu de la Pedagogie socială. Sever Pop este încadrat la Facultatea de Litere și Filosofie din Iaşi, după suprimarea celui de-al doilea post de la catedra de Limbă română și dialectele ei, iar Victor Papacostea este trecut cu titlul şi salariul de profesor universitar la Institutul de Cercetări Balcanice din București, în urma comprimării catedrei de Istoria popoarelor balcanice cu privire specială la românii din sudul Dunării.

\footnotetext{
${ }^{132}$ Ibidem, p. 8950.

${ }^{133}$ Decizia nr. 257.823 și Decizia 257.824 în Monitorul Oficial, nr. 232, 8 octombrie 1947, p. 9045.

${ }^{134}$ Idem, nr. 239 din 16 octombrie 1947, pp. 9 293-9 299.
} 
În schimb, Andrei Oțetea, în măsura în care, catedra de Istorie Economică se desființează, trece deloc dezinteresat, la cea de Istorie Universală de unde fusese epurat Gheorghe Brătianu și odată cu aceasta preia și directoratul asupra Institutului pentru Studiul Istoriei Universale. Alte desființări de catedre, conferințe și posturi iau vizat pe Ioan Hudiță, Istoria diplomației, Gh. Cantacuzino, Instituții și istorie greco-romană, Alexandru Busuioceanu, Istoria artelor, Constantin Micu, asistent provizoriu în specializarea Epistemiologie și metafizică la catedra de Istoria Filosofiei moderne și contemporane, Dumitru Șandru, asistent provizoriu în materia Limba română și dialectele ei, Constantin (Dinu) Pilat, Adrian Marino și Barbu Teodorescu, asistenți suplinitori la catedra de Istoria literaturii române moderne. Un alt rând de asistenți era îndepărt după cum urmează: Vera Cancel, de la catedra de Slavistică, Constantin H. Niculescu, de la cea de Limbă și literatură italiană, Florin Stănculescu, de la catedra de Istoria Românilor iar Paul Radu, de la cea de Estetică și Critică literară. Prevederi oarecum particulare îi priveau pe Alexandru PopescuTelega de la catedra de limbă spaniolă, în cazul său, comprimându-se persoana cu drept de pensionare și pe I. Şiadbei, în cazul căruia se comprima și se suspenda temporar plata salariului.

Universitatea din Cluj pierdea, de asemenea, posturi esențiale. Profesorii Leon Nicolae și Cristofor Coroamă erau comprimați de la catedra de Finanțe și Statistică, respectiv Economie politică și istoria doctrinelor economice de la Facultatea de Drept.

Epurați, fără posibilitatea de a se mai întoarce în mediul universitar, au fost de asemenea, profesorii Nicolae Mărgineanu, de la conferinţa de Psihologie aplicată, Dumitru Mateiaș, asistent la catedra de Introducere în filozofie, Grigore Popa, la cea de Filozofie generală, Liviu Onu, asistent la catedra de Istoria literaturii române vechi de la Facultatea de filosofie și litere, cărora li se adăuga Iosif Ion Rusu, de la Institutul de studii clasice. La Universitatea din Iași, unde avuseseră loc în trecut cele mai drastice epurări din sistemul universitar, în paralel cu profesorii și asistenții de la Facultățile de Teologie şi Drept, procedurile de comprimare i-au exclus din cadrele profesionale pe Șerban Cioculescu de la catedra de Istoria literaturii române moderme, Petre Caraman, de la cea de Slavistică, Victor Iancu, conferențiar la conferința de Estetică Filosofică, Elena Irion, asistent la cea de Sociologie și Etică, Grigore Scoran, la Istoria literaturii române vechi, Ștefan Nimph, la Limba franceză, Anton Nițu, asistent la catedra de Arheologie și preistorie iar lista se încheia cu Mihai Guboglu, de la catedra de Turcologie. Nu era uitat nici Institutul de Istorie Naţională „A.D. Xenopol”, unde erau desființate posturile a doi asistenți, în timp ce un șef de lucrări era trecut la catedra de Istoria românilor.

O ultimă decizie care întregește sfera procedurilor de epurare se concretizează prin comprimarea temporară a salariilor mai multor asistenți, 
conferențiari și profesori universitari, dar și a celor care dețineau funcții de conducere la institutele de pe lângă Universităţi ${ }^{135}$. Conform cercetărilor întreprinse de Maria Someșan și Mircea Iosifescu, în toate instituțiile de învățământ superior, existente la acea dată, au fost desființate ,peste 500 de posturi didactice superioare, simultan, pierdere puternic resimțtiă în multe facultăți’"136, dar oricât de impresionant ar fi acest prim val de „epurare” dimensiunile sale au fost limitate de imposibilitatea înlocuirii imediate cu un alt corp profesoral obiedient Partidului Comunist, confirmându-se astfel temerile exprimate de prof. Traian Săvulescu. La aproximativ o lună de la emiterea deciziilor mai sus-menţionate, se revenea asupra unor comprimări, iar astfel de măsuri au fost luate pe tot parcursul anului universitar. Este foarte adevărat că ele au vizat doar domeniile ştiințifice precum chimia tehnologică, electromecanică, farmacologie, patologie generală, embriologie, fiziologie vegetală și altele, unde problema formării și dezvoltării de specialiști se punea în mod acut, însă prin contrast cu perspectiva de schimbare totală de la care s-a pornit, aceste reveniri asupra unor decizii redimensionează totuși amploarea fenomenului. Puținele rechemări în domeniile socio-umane i-au privit pe: Ion Chelcea (conferința de Etnografie de la Facultatea de Științe), Pimen Constantinescu (asistent limba italiană la Academia de Înalte Studii Comerciale Brașov) și Anton Nițu (asistent la catedra de arheologie și preistorie de la Facultatea de Litere și Filozofie din Iași $)^{137}$. În rest, Iorgu Iordan trece de la catedra de lingvistică generală la cea de Filologie Romanică, iar Ion Balmuş se transferă de la Iași la București, deoarece cadrul legal permitea mutații în cadrul personalului deja existent ${ }^{138}$.

Singurele intrări în sistemul de învățământ universitar, intervenite oricum la sfârșitul termenului pentru care posturile fuseseră blocate ${ }^{139}$, identificate de noi, au fost cele ale lui Alexandru Piru, ca asistent la catedra de Istorie a literaturii române, Mitiță Constantinescu, profesor agreat la catedra de Procedură Civilă de la Facultatea de Drept din Iași și C. Ionescu Gulian la conferința nou-înființată de Introducere în Filozofie la Facultatea de Litere și Filozofie București ${ }^{140}$.

\footnotetext{
${ }^{135}$ Idem, nr. 239, 16 octombrie 1947, pp. 9 299-9 307.

${ }^{136}$ Maria Someșan, Mircea Iosifescu, op. cit., p. 474.

${ }^{137}$ Monitorul Oficial nr. 121, 27 mai 1948, p. 4 663; idem, nr. 130, 7 iunie 1948, p. 4 937; idem, nr. 160, 20 iulie 1948, p. 6000.

${ }^{138}$ Idem, nr. 28, 4 februarie 1948, p. 923 și idem, nr. 50 din 1 martie 1948, p. 1857.

${ }^{139}$ La 2 martie 1948 a fost publicată Legea nr. 55 pentru completarea art. 61 din Legea nr. 386 din 1943, relativ la organizarea învățământului superior prin care Ministerul Educației Naționale putea hotărî aplicarea de la început a oricăreia din procedurile prevăzute la articolele 63, 64, 64 Bis şi 65 pentru ocuparea catedrelor și conferințelor vacante (Idem, nr. 51, 2 martie 1948, p. 1895 ).

${ }^{140}$ Idem, nr. 64, 17 martie 1948, p. 2 333; idem, nr. 59, 11 martie 1948, p. 2 150; idem, nr. 168, 23 iulie 1948, p. 6085.
} 
Pe de altă parte, pentru a avea un tablou complet al epurărilor din mediul universitar trebuie să luăm în considerare și celelalte forme de ingerință politică echivalente despre care s-a vorbit mult prea puțin până acum.

În prima jumătate a anului 1948 erau puși în disponibilitate pentru că nu au depus jurământ de credință, absolut obligatoriu pentru toți profesorii ${ }^{141}$, către nou instaurata Republică Populară Română, Basil Munteanu, Scarlat Lambrino și Sever Pop $^{142}$. Apoi, în prefigurarea înființării unui singur Institut de Istorie al R.P.R., Constantin C. Giurescu era suspendat din postul de director al Institutului de Istorie Naţională București, Silviu Dragomir era desărcinat din cel de director al Centrului de Studii și Cercetări privitoare la Transilvania, în timp ce la Iași, Alexandru Boldur demisiona din fruntea Institutului „A.D. Xenopol”143.

O altă măsură a cărei motivație se pare că a fost mult mai adâncă decât înlăturarea unor profesori indezirabili noii ordini politice s-a consumat în primăvara anului 1948, când prin Legea nr. 87 pentru raționalizarea învățământului teologic universitar, Facultatea de Teologie de la București și cea de la Suceava au fost comasate, practic, într-una singură şi odată cu aceasta, o comisie numită de ministrul Educației Naţionale a dispus încadrările la catedrele, conferințele și asistențele acestei nou organizate instituții de învățământ ${ }^{144}$.

Facultatea de Teologie din Cernăuți, refugiată în primăvara anului 1944 la Suceava, pusese un accent deosebit, încă de la inaugurarea sa, ca parte a Universității Germane din capitala Bucovinei, în ziua de 4 octombrie 1875, pe Teologia Practică, în fapt singura materie care s-a predat, până în 1918, în limba română, respectiv ucraineană.

141 La nivelul memorialisticii, trecută, ca profesoară de limbă franceză, prin experiența schimbării noului curs al României cu tot ceea ce implica aceasta, Ecaterina BălăcioiuLovinescu ne aproprie de atmosfera epocii într-una dintre Scrisorile către Monica, datată chiar 1 ianuarie 1948: „N-am plâns, Monica, n-am plâns. Și nici nu am blestemat; am strâns pumnii de sigurătatea și tristețea ce mă zguduie ca fiorii de friguri. Eri după masă, în fața lui Neș [Dej], am depus jurământ de credință către Republica Populară Română; acolo ni s-au comunicat lucruri ce vor apare și în jurnale, de altminteri: că liceul unde profesez se va numi de acum înainte Liceul Teoretic nr. 2, că numele familiei Hohenzollern va dispare din nomenclatura școlilor și cred că și a străzilor; cred că în viitoarea mea scrisoare îți voi comunica numele nou" (Ecaterina Bălăcioiu-Lovinescu, Scrisori către Monica 1947-1951, traducerea scrisorilor din limba franceză de Gabriela Creția; selecția și îngrijirea textelor, prefață, tabel cronologic și note de Astrid Cambose, București, Editura Humanitas, 2012, p. 190).

${ }^{142}$ Monitorul Oficial nr. 72, 26 martie 1948, p. 2 634; Idem, nr. 133 din 11 iunie 1948, p. 5 040; Idem, nr. 168, 23 iunie 1948, p. 6085.

${ }^{143}$ Idem, nr. 128, 4 iulie 1948, p. 4 877; idem, nr. 131, 8 iunie 1948, p. 4970 și idem, nr. 133, 11 iunie 1948, p. 5040.

${ }^{144}$ Idem, nr. 78, 2 aprilie 1948, pp. 2 925-2 926; idem, nr. 83, 8 aprilie 1948, p. 3 127; idem, nr. 86, 12 aprilie 1948, p. 3319. 
La sfârșitul perioadei de tranziție spre instituţionalizarea comunismului, în special, activitatea de catehizare în rândul elevilor din instituțiile de învățământ preuniversitare, întreprinsă de studenții teologi ai respectivei facultăți, a fost privită drept un obstacol esențial în calea pătrunderii organizațiilor de partid în aceste instituții cu tot ceea ce presupunea acesta la nivelul mobilizării publice și propagandistice în scopul creării „omului nou”. Ceea ce s-a întâmplat cu Facultatea de Teologie de la Suceava nu a fost însă un caz singular. Din aceleaşi cauze, activitatea asociaţiei nonguvernamentale Young Men's Christian Association (Asociația Creștină a Tinerilor) a fost supravegheată și combătută prin mesaje denigratoare de către Siguranță, respectiv responsabilii secțiilor de educație politică, până la desființarea sa ${ }^{145}$.

Sfârşitul anului școlar și universitar 1947-1948 se încheia prin Decizia Ministerului Învățământului Public nr. 162.067 din 23 iunie 1948 pentru rezilierea tuturor contractelor de angajament privind personalul didactic și știinţific din învăţământul superior și secundar pe data de 1 octombrie $1948^{146}$. Ea nu a avut, în general, doar rolul ce i se acordă retrospectiv, de eliminare din învăţământul superior a unui al doilea val de profesori eminenți, cât mai ales unul de negociere, foarte adevărat de pe poziții de putere, a unui raport de încredere între spațiul politic și cel şcolar şi universitar.

Mutaţii importante se produc pe parcursul acestui an universitar și la nivelul controlului politic al Ministerului Educației Naţionale. Un obiectiv principal în cucerirea puterii politice de către comuniști a fost reprezentat, imediat după 23 august 1944, de preluarea controlului asupra „sectoarelor-cheie, în special armata, justiţia și internele"147.

Un minister precum cel al educației nu a fost un imperativ al momentului și oricum deținerea sa de către Ștefan Voitec, începând cu al doilea guvern Constantin Sănătescu, nu a împiedicat nucleul comunist ca ,prin Comisia de învățământ public din cadrul Secției Centrale de Educație Politică să îl dubleze și să îl supravegheze pe ministru sau să-şi extindă controlul asupra sistemului educațional, inclusiv prin recrutarea de profesori în sindicatele procomuniste și în partid" ${ }^{148}$. Aceasta în timp ce la conducerea universităților, prin încălcarea autonomiei universitare, au fost promovate personalități intrate în siajul comuniștilor iar pentru primul val de epurări politice din toamna anului 1947 a fost creat un cadru legal ce nu putea fi eludat.

${ }^{145}$ Cristian Vasile, Literatura și artele în România comunistă 1948-1953, București, Editura Humanitas, 2010, p. 262.

${ }^{146}$ Monitorul Oficial nr. 142, 23 iunie 1948, p. 5289.

${ }^{147}$ Jean-François Soulet, Istoria comparată a statelor comuniste din 1945 până în zilele noastre, Iași, Editura Polirom, 1998, p. 23.

${ }^{148}$ Cristian Vasile, op. cit., p. 212. 
Nimic din ceea ce-i reproșau comuniștii lui Ștefan Voitec, în diverse referate și analize care ajungeau pe birourile Secției Centrale de Educație Politică a C.C. a P.C.R., nu era nou în mod deosebit doar că pe fondul acestei radicalizări politice, diferite aspecte tolerate până atunci, deveneau brusc de neiertat. În fapt ele erau indicii asupra modificărilor ce aveau să fie operate în sistemul de învățământ. Totodată, în contextul viitorului prim Congres al P.M.R. (21-23 februarie 1948) în cadrul căruia era preconizată, după cum se cunoaște, unificarea sau dizolvarea Partidului Social Democrat cu/în Partidul Comunist Român, mișcare politică în care Ştefan Voitec se poziţionase în favoarea comuniştilor, mai mult decât afirmarea cursului care avea să fie urmat în educație, Ștefan Voitec nu va avea de înfruntat alte repercusiuni.

Odată cu proclamarea R.P.R. la 30 decembrie 1947 și abrogarea Constituției din 1923 este ales în Prezidiul provizoriu al acesteia, alături de C.I. Parhon, Mihail Sadoveanu, Gh. I. Stere și I. Niculi, până la adoptarea unei noi legi fundamentale. Pe acest fond, ministru ad-interim al Ministerului Educaţiei Naţionale este desemnat Lothar Rădăceanu, ministrul Muncii și Prevederilor Sociale, ministerul fiind condus, de fapt, de Gheorghe Vasilichi, vechi ilegalist, propulsat subsecretar de stat în Ministerul Educației încă din 12 noiembrie 1947, de Ana Puker și GheorgheGheorghiu Dej, după înlăturarea din guvern a miniștrilor tătărescieni ${ }^{149}$.

${ }^{149}$ Momentul este redat de Memoriile lui Gheorghe Vasilichi, publicate prin eforturile lui Gheorghe Neacșu: „Pe la jumătatea lunii octombrie 1947 au trecut Gheorghiu-Dej și Ana pe la mine. Ei m-au pus la curent, că, dat fiind că Tătărescu și grupa lui își fac de cap şi sub motiv că rușii nu ne pot ajuta, greutățile provocate de secetă fiind mari, susțineau neapărat să apelăm la Apus pentru ajutor. Se pare că a plecat la Londra cu treburi, și începuse tratative cu niște bancheri și trusturi monopoliste, cu gândul că dacă noi nu vrem să mergem cu el, el va rupe alianța, va forma un nou guvern și o va face el singur. În această problemă el avea desigur asentimentul şi tot sprijinul, atât al regelui, cât și al lui Maniu și Brătianu, aşa că a sosit momentul să-i excludem din guvern și să lichidăm alianța cu ei. Mi-au arătat și cine va intra în guvern în locul lor, la Ministerul de Externe și la cel de Finanțe, și anume Ana Pauker și Vasile Luca. Am fost întrebat ce cred eu, dacă sănătatea îmi permite ca să intru și eu în guvern, ca subsecretar de stat la Ministerul Educației Naționale, unde secretar de stat [ministru n.n.] era Ștefan Voitec. Eu care mă refăcusem destul de bine și mă plictiseam grozav la Predeal, nefăcând nimic și știind cât muncesc ceilalți tovarăși, am acceptat bucuros să încep munca, numai [că] mă îndoiam, dacă eu, cu 4 clase primare sunt cel mai potrivit să lucrez la Ministerul Educației. Mai gândiți-vă - le-am spus eu - poate mă dați la Agricultură sau în altă parte. Ei m-au asigurat că am să fac față, întrucât voi fi ajutat de tovarășii de la Secția Culturală a C.C. și de către Biroul Politic. Ne-am înțeles și ai au plecat - urmând ca eu să fiu anunțat când să viu la București” (Gheorghe Neacșu, „Din amintirile unui ilegalist Gheorghe Vasilichi", în Arhivele Totalitarismului, Anul VIII, nr. 28-29; nr. 3-4/2000, pp. 119-120). 
La începutul anului 1948 i se stabilesc competențe foarte largi ${ }^{150}$, însă de abia după alegerile din 28 martie 1948, constituirea Marii Adunări Naţionale și formarea noului guvern devine ministru al Învățământului Public ${ }^{151}$, secondat de Constatin Daicoviciu ca ministru adjunct ${ }^{152}$.

Proces derulat treptat, în strânsă legătură cu etapele preluării puterii politice, precondițiile preluării controlului absolut al educaţiei și învăţământului erau astfel desăvârşite, pentru pasul final reprezentat de Decretul nr. 175 din 3 august 1948 pentru reforma învâțământului.

\section{Implicațiile reformei din 3 august 1948 asupra învățământului superior}

Preluarea controlului asupra educaţiei și a învățământului, desfășurată treptat după 23 august 1944, avea să se materializeze, într-un mod decisiv, odată cu Decretul nr. 175 din 3 august 1948 pentru reforma învățământului, decret care conținea „foarte puține capitole și articole pentru o lege unică a învățământului de toate gradele" ${ }^{" 153}$, dar contribuia ireversibil la adoptarea unei paradigme educaționale sovietice, trecută deja prin eșecul unor experimente transformiste radicale care nu garantaseră însă un nivel de pregătire ridicat ${ }^{154}$ în consecință au fost abandonate încă

${ }^{150}$ Era autorizat să rezolve orice problemă privind învățământul de toate categoriile, problemele de educație a tineretului în școli, precum și cele legate de contabilitate, contencios, serviciul tehnic, personalul administrativ, Casa Școalelor și a Culturii Poporului și Casa de Economie, Credit și Ajutor a Corpului Didactic, cu excepția acelora care prin lege erau rezervate ministrului. De asemenea putea semna deciziile privind mișcarea de personal. Se ratificau totodată și acele aprobări date de Gheorghe Vasilichi de la data numirii ca subsecretar de stat până la data publicării acestei decizii de stabilire a competențelor (Monitorul Oficial nr. 13, 16 ianuarie 1948, p. 390).

${ }^{151}$ Idem, nr. 88, 14 aprilie 1948, p. 3 405; Odată cu formarea noului guvern, titulatura de Minister al Educației este înlocuită cu cea de Minister al Învățământului Public, ceea ce prefigura organizarea de către stat a întregului proces de pregătire a elevilor și desființarea filierelor paralele de educație precum școlile particulare sau confesionale.

${ }^{152}$ Idem, nr. 95, 22 aprilie 1948, p. 3693.

${ }^{153}$ Dănuț Doboș, Reforma învățământului Decretul 175/1948 în „Arhivele Totalitarismului”, Anul III, nr. 3/1995, București, Editura Academiei Române, 1995, p. 202.

154 Supranumite de Vladimir Berelowitch „futurismul pedagogic al anilor '20", experimentele respective au fost un amestec ciudat de idei educaţionale provenite din spațiul occidental, a căror finalitate era dezvoltarea liberă a personalității copilului și deziderate totalitare circumscrise formării militantului comunist, încă de pe băncile școlii. Situația se va schimba brusc la sfârşitul anilor'20 și începutul anilor '30. Parte a „revoluției de sus” impusă de Stalin întregii societăţi, în domeniul învățământului se revine la modelul tradiționalist de însuşire, acumulare și verificare a cunoștințelor iar în ceea ce ne interesează „au fost reintroduse examenele de intrare la Universitate" (vezi pe larg, Mariana Momanu, op. cit., p. 98. 
din 1929. Ne referim, în principal, la posibilitatea înscrierii la școlile superioare fără studii liceale finalizate și fără susținerea unui examen, singura condiție fiind cerința de a avea 16 ani împliniți și la susținerea unui examen, la care se alătura schimbarea programelor din învățământul superior în sensul privilegierii caracterului eminamente practic în detrimentul celui teoretic. Există însă și schimbări importante de sorginte sovietică mergând de la desființarea autonomiei universitare, transformarea facultăților în institute superioare (mai ales cele tehnice), ideologizarea în scopul „educării tineretului în spiritul democrației populare” până la gratuitatea învățământului superior și acordarea de burse pe criterii sociale, copiate şi adaptate, după cum vom vedea, și în România.

În primul rând, aşa cum a analizat istoricul Dănuț Doboș, articolele XVIXXIV și XXII referitoare la învățământul superior din Decretul nr. 175 pentru reforma învățământului nu au fost urmate de o lege de organizare a acestuia „care să-i definească statutul, fie chiar de esență comunistă, regimul mulţumindu-se doar cu elaborarea incoerentă a unor acte normative, cele mai multe de inspirație sovietică" ${ }^{n 155}$.

În al doilea rând, desființarea autonomiei universitare şi a Senatelor universitare, atât cât mai subzistaseră în perioada de tranziție, transpare într-un mod implicit, nu explicit din Decizia nr. 263.327/26 octombrie 1948 referitoare la organizarea învățământului superior. Conform acesteia Universitățile depindeau de Ministerul Învățământului Public iar Institutele Superioare fie de acesta, fie de alte ministere (art. 2-3), în timp ce, conducerea instituțiilor de învățământ superior era asigurată doar de către rectori și decani (art. 4), aceste prevederi asigurând practic subsumarea învățământului superior, factorului politic ${ }^{156}$.

În privința restructurării instituțiilor superioare, fără a desființa universitățile și politehnicile, formele tradiţionale ale învățământului de până atunci, regimul le alătură, după model sovietic, Institute de învățământ superior (Decretul nr. 175/3 august 1948$)^{157}$, pentru ca apoi, posibil, datorită lipsei posibilităţilor financiare şi logistice în a crea masiv noi astfel de institute, să împartă organizarea învăţământului superior în Universităţi și Institute Superioare de Învăţământ

\footnotetext{
155 Dănuț Doboș, Epurări la Universitatea din Iași. 1949-1960 în „Arhivele Totalitarismului", Anul II, nr. 1-2/1994, București, Editura Academiei Române, 1994, p. 44. ${ }^{156}$ Monitorul Oficial nr. 249, 26 octombrie 1948, pp. 8 522-8 525.

${ }^{157}$ Reforma învățământului, așa cum era ea anunțată de Gheorghe Vasilichi, presupunea că ,învățământul superior se va compune în afară de universități și politehnici, cu misiuni pedagogice și științifice generale, din institute de învățământ superior, create în mod special pentru a asigura vieții economice, un nivel tehnic și științific ridicat. Ele au menirea să creeze în primul rând cadre superioare de specialiști, destinați producției ca: ingineri, medici, agronomi, profesori, aşadar profesioniști (,Agerpres”, nr. 336 din 5 august 1948).
} 
(Decizia nr. 263.327/26 octombrie 1948), Politehnicile, fiind înglobate în această ultimă categorie.

Perioada de tranziție 23 august 1944-3 august 1948 nu fusese lipsită de încercarea materializării unor mai vechi iniţiative fondatoare de învățământ universitar, acolo unde a existat o incidență a necesităţilor sociale cu cele ale primului guvern procomunist ${ }^{158}$ însă aceeași precaritate a vieții economice a redus mult din proiectele inițiale. Poate cel mai elocvent caz este cel al Universității de Vest din Timișoara. Înființată la 31 decembrie 1944, într-o atmosferă de consens politic general, cum rar a existat în perioadă, consens ce reunea în comitetul de acțiune, de la Sever Bocu, P.N.Ț. - ist și inițiator al proiectului universitar, la dr. Petru Groza, vicepreședinte al Guvernului, președinte al Frontului Plugarilor și Victor Papacostea, P.N.L.-ist, conferindu-i-se aceeași structură ca Universitatea din București ${ }^{159}$, în cele din urmă instituția de învățământ superior bănățeană își începea activitatea doar cu facultățile de Medicină Veterinară și Medicină Umană ${ }^{160}$.

Ceva mai prudent, textul Legii nr. 138 pentru înființarea Universității din Craiova și a Eforiei ei din 25 aprilie 1947, cea de-a doua inițiativă a perioadei de tranziţie, mult așteptată de intelectualitatea Olteniei, prevedea funcționarea acesteia deocamdată cu Facultățile de medicină umană, medicină veterinară, de științe economice, comerciale, cooperatiste și de agronomie (art. 2), cursurile facultăţilor urmând a se deschide la începutul anului universitar 1947-1948 numai pentru anii pentru care a fost posibilă organizarea de catedre (art. 3) și lăsa prin art. 4 posibilitatea completării cu alte facultăți pe măsura necesităților ${ }^{161}$, numai că, din aceleași motive legate de insuficiența resurselor bugetare, pentru moment, s-au pus doar bazele învățământului superior agronomic ${ }^{162}$.

158 În aceeași perioadă se renunță la înființarea de facto a Institutului Regal român de cercetări internaționale și științe politice de pe lângă Ministerul Afacerilor Străine prin abrogarea Legii nr. 216/1944, mai mult din motive care țineau de catalogarea sa drept o creație artificială a vechiului regim dictatorial decât de preocupările nucleului guvernamental pro-comunist de a crea premisele instituirii monopolului ideologic asupra gândirii politice. Raportul care însoțea această măsură legală era semnat de Ministrul Afacerilor Străine, Constantin Vișoianu și, alături de argumentul sus-amintit, propunea stimularea acestor studii în cadrul învățământului universitar deja existent (Monitorul Oficial, nr. 35, 13 februarie 1945, pp. 1 001-1 002).

${ }^{159}$ Legea nr. 660 pentru înființarea Universității de Vest în Monitorul Oficial nr. 302, 31 decembrie 1944, pp. $8462-8464$

${ }^{160}$ La 4 mai 1945 este publicată Legea $n r .361$ pentru modificarea unor dispoziții din legea pentru inființarea Universității de Vest. Practic, conform art. 2 aceasta urma să funcționeze deocamdată numai cu Facultățile de Medicină umană și Medicină veterinară (Idem, nr. 102, 4 mai 1945 , pp. 3 698-3 700).

${ }^{161}$ Idem, nr. 93, 25 aprilie 1947, pp. 3 223-3 226.

${ }^{162}$ Idem, nr. 38, 16 februarie 1948, pp. 1 315-1 316. 
Reîntorcându-ne la anul universitar 1948/1949, acesta debuta cu 47 instituții de învățământ superior ce cuprindeau 129 facultăți în care erau încadrate 5.638 de cadre didactice, numărul studenților cifrându-se la $48.676^{163}$, cele mai mari schimbări suferindu-le Universităţile.

Redenumite, Universitatea „C.I. Parhon”, în București, Universitatea „Alexandru Ioan Cuza”, în Iași, Universitatea „Victor Babeş”, în Cluj, la care se adăuga „Universitatea de Stat Bolyai cu predare în limba maghiară" ${ }^{164}$, fiecare dintre acestea avea în compunerea sa facultăți de Filologie, Istorie-Geografie, Filozofie, Pedagogie și Psihologie, Matematică și Fizică, Științe Naturale, Chimie și Științe Juridico-Administrative, în ceea ce ne interesează, fosta Facultate de Litere și Filozofie fiind împărțită, așa cum se observă, în mai multe facultăți ${ }^{165}$. Privilegiat este învăţământul științific și tehnic în timp ce ideologizarea şi politizarea învățământului, materializată în programele de învățământ este impusă în toate instituțiile ${ }^{166}$, în paralel cu anihilarea învățământului teologic ${ }^{167}$.

163 Ovidiu Bozgan, Bogdan Murgescu (coordonatori), Universitatea din Bucureşti 18642014, București, Editura Universității din București, 2014, p. 285.

${ }^{164}$ Constituită legal prin Decretul regal nr. 407 din 29 mai 1945 și prevăzută a funcționa cu facultăți de Litere și Filozofie, Drept și Economie Politică, Științe și Medicină umană, un rol important în privința înființării sale l-a avut contextul extern, şi anume, protecția acordată de către U.R.S.S., minorității maghiare din Transilvania. Nemulțumirile Uniunii Populare Maghiare exprimate într-o ședință din 31 mai 1945 au fost numeroase, nu însă de natură a determina modificări ale cadrului legislativ. Pe de altă parte, dificultăţile generate de organizarea practicii medicale în clinicile clujene a condus la decizia ca, Facultatea de Medicină a Universității Bolyai să ființeze la Târgu Mureș. În urma organizării învățământului superior din 26 octombrie 1948, aceasta a fost transformată în Institutul de Medicină și Farmacie Târgu Mureș (vezi pe larg, Andreea Andreescu, Regimul comunist și problema Universității Maghiare din Cluj (1945-1959) în Mirela Luminița Murgescu, Simion Câlția (coord.), Exerciții întru cunoaștere Societate și mentalități în noi abordări istoriografice, București, Editura Dominor, 2003, pp. 147-166).

${ }^{165}$ Decizia nr. 263.327 privind organizarea învățământului superior în Monitorul Oficial, nr. 249, 26 octombrie 1948, pp. 8 522-8 525.

$166 \mathrm{O}$ interesantă evocare a clivajului între realitatea cotidiană și ideologizarea învățământului, cu toate situațiile hilare generate de lipsa de specialiști în ,științe sociale" sau de ostilitatea studenților față de acestea dar și a efectelor dintre cele mai dezastroase pentru nivelul de pregătire, reconstituie Andrei Cosmovici, în studiul Viața universitară în communism. O perspectivă psihosociologică (Adrian Neculau, coord., Viața cotidiană în comunism, Iași, Editura Polirom, 2004, pp. 47-58).

${ }^{167}$ Redus până la desființare, în expresia unui istoric al învățământului confesional, prin Decretul nr. 176/3 august 1948 privind trecerea în proprietatea statului a bunurilor bisericilor, congregațiilor, comunităților sau particularilor și prin Decretul nr. 177/3 august 1948 privind organizarea cultelor religioase din România, școlarizarea elevilor și studenților cultelor religioase, fost reglementată prin Decizia nr. 42898 a Ministerului Justitiiei (Dănuț Doboș, Reforma învățământului Decretul 175/1948 în „Arhivele Totalitarismului”, Anul III, nr. 3/1995, p. 205 și Monitorul Oficial, nr. 266, 15 noiembrie 1948, pp. 9 175-9 178). 


\section{I. Studenții și implicațiile reformei din 3 august 1948 asupra învățământului superior}

Organizarea învățământului superior, de așa manieră, încât să fie subsumat factorului politic, nu a fost unica expresie a dorinței de schimbare. O maximizare a asistenței sociale de stat către studenți s-a realizat la scară mai redusă față de școlarizarea superioară de primă generație în U.R.S.S., ceea ce nu-i diminuează caracterul de element-cheie în preocuparea creării unor cadre devotate cauzei comuniste.

După eșecul suferit în U.R.S.S., nu putem eluda faptul că, posibilitatea înscrierii fără diplomă (a studiilor gimnaziale și liceale) a fost coborâtă în România doar la nou createle școli speciale de doi ani (transformate în 1953 în facultăți muncitorești), a căror absolvire compensa lipsa pregătirii medii și conferea dreptul de înscriere în instituțiile de învățământ superior, pentru oamenii aflați în câmpul muncii $^{168}$.

O măsură cu o vizibilitate, într-adevăr imediată, pe teren social, odată cu anul universitar 1948-1949, este aceea care lărgește procentul beneficiarilor de burse studențești. Potrivit unui Material informativ asupra situației asistenței de stat pentru studenți, identificat de istoricul Nicoleta Ionescu-Gură în arhiva C.C. al P.C.R., dacă în anul universitar 1946-1947 au fost alocate burse unui număr de 11. 984 studenți, adică unui procent de (22\%) din totalul lor, în anul universitar 19481949 se ajunge la un număr de 24000 studenți adică la un procent de 56\% în condițiile în care studenții plătitori de taxe nu mai aveau acces la un astfel de beneficiu social ${ }^{169}$. În paralel, parte a instalării irevocabile a unui sistem social de selecție, taxele de studii, menţinute după reforma învăţământului din 3 august 1948 până târziu în 1961, devin instrumente de eliminare a categoriilor indezirabile ${ }^{170}$.

\footnotetext{
${ }_{168}$ Maria Someșan, Mircea Iosifescu, Legile din 1948 pentru reforma învățământului în „Analele Sighet 6, Anul 1948 - Instituționalizarea comunismului”, București, Fundația Academia Civică, 1998, pp. 441-442.

${ }^{169}$ Nicoleta Ionescu-Gură, op. cit., p. 351.

170 „În 1949 am dat examen de admitere la Facultatea de fizică din Cluj, am reușit excelent, cu medie mare. S-a încercat atunci să se pună o stavilă în calea intrării mele la facultate (pentru că eram fiica lui Blaga, adică originea mea socială nu convenea) prin stabilirea unei taxe de școlarizare pe care părinții mei nu o puteau plăti (era la un an după reforma învățământului și unii studenți mai plăteau taxe). Până la urmă organizația de studenți m-a salvat, reprezentată de Herman Schmidt și Oliviu Gherman; s-a stabilit o taxă suportabilă și am început facultatea. Trebuie să spun că la Universitatea Victor Babeș din Cluj, atmosfera era mult mai suportabilă decât la Universitatea din București. Între studenți exista un spirit de echipă, indiferent dacă aveai «origine sănătoasă» sau «nesănătoasă»", scria Dorli Blaga, fiica
} 
Circumscrise formării unei „noi intelectualități ieșită din rândurile muncitorimii, țărănimii și ale celei progresiste" așa cum afirma Gheorghe Gheorghiu Dej în raportul prezentat la primul congres al Partidului Muncitoresc Român (21-23 februarie 1948), au fost măsurile de excludere socială ce debutau în anul universitar 1948-1948 printr-o amplă verificare a originii sociale a studenților ${ }^{171}$. În timp, i se vor alătura două importante acte normative și anume Directiva Biroului Politic cu privire la măsurile necesare imbunătățirii compoziției de clasă a elevilor și studenților adoptată la 28 iulie 1952 care împărțea viitorii studenți în trei categorii sociale, în cea de-a treia fiind situați fii de chiaburi, comercianți, industriași și alți exploatatori și Hotărârea C.C. al P.M.R. şi a Consiliului de Miniştri din 25 iunie 1957 cu privire la creșterea procentului de fii de muncitori și de țărani la 70-75\% din totalul studenților ${ }^{172}$. Cum aceste acte normative nu eliminau în sine candidații indezirabili, de la înscrierea în instituțiile de învățământ superior, o încercare de reconstituire a funcționării mecanismului de excludere, mai ales în cazul Directivei Biroului Politic din 1952, reliefează faptul că, de pildă, „nota la examenul de admitere se scădea automat cu un punct la candidații proveniți din categoria a doua" ${ }^{\text {"173. }}$ O analiză strict statistică ne arată că ponderea studenților proveniţi din rândurile muncitorilor și țăranilor a depășit-o pe cea a celor proveniți din rândul funcționarilor de stat, de abia în anul 1958, pentru ca raportul dintre cele două să se echilibreze până spre anul 1965-1966, alături de modificarea perceperii realităților sociale, după două decenii de socialism ${ }^{174}$.

Fapt mai puțin sesizabil, pe un palier mai jos, alte măsuri luate în 1948, precum cele enumerate de Adina Berciu-Drăghicescu, și anume: „introducerea a două sesiuni speciale de examene pentru lichidarea celor restante, obligativitea frecventării cursurilor și seminariilor sau promovarea într-un an de studiu superior numai după absolvirea examenelor din anii precedenți”"175 par a pune capăt mai mult slăbiciunilor perioadei de după Primul Război Mondial, dacă ne gândim atât la revendicările societăților studențești ale acesteia cât și la pozițiile rectoratelor, decât a fi fost desprinse din modelul sovietic.

lui Lucian Blaga (Dorli Blaga, Tatăl meu, Lucian Blaga, București, Editura Humanitas, 2012, p. 36).

${ }^{171}$ Vladimir Tismăneanu, Dorin Dobrincu, Cristian Vasile (editori), op. cit., p. 289.

172 vezi pe larg, Nicoleta Ionescu-Gură, op. cit., pp. 341-356.

${ }^{173}$ Vladimir Tismăneanu, Dorin Dobrincu, Cristian Vasile (editori), op. cit., p. 303.

${ }^{174}$ Ovidiu Bozgan, Bogdan Murgescu (coordonatori), op. cit., p. 325.

${ }^{175}$ Adina Berciu Drăghicescu, Facultatea de Litere a Universității din București. 150 de ani de învățământ filologic românesc 1863-2013, Partea I, București, Editura Universității din București, 2013, p. 160. 


\section{II. Profesorii și implicațiile reformei din 3 august 1948 asupra} invățământului superior

Epurările cu caracter politic, sub pretextul reducerii cheltuielilor bugetare, din anul universitar 1947-1948 au permis înlăturarea celor care prin influența cuvântului lor în cadrul instituțiilor superioare, dar și, asupra studenților ar fi putut compromite atât politizarea cât și procesul rapid de preluare a controlului total asupra învăţământului superior de către Partidul Comunist. Cei mai afectați au fost desigur profesorii, conferențiarii și asistenții învăţământului umanist, în cazul celui științific revenindu-se, în foarte multe cazuri, asupra comprimărilor universitare. Așa se face că, cel puțin la Universitatea din București, unde există date precise, în anul universitar 1948-1949, „mai subzistau din personalul didactic anterior datei de 3 august 1944, [doar] 3,4\% la Facultatea de filozofie, 23\% la Facultatea de filologie, 35\% la Facultatea de drept, 36\% la Facultatea de istorie-geografie [şi], 40\% la Facultatea de chimie, 50\% la Facultatea de științe naturale și $60 \%$ la Facultatea de matematică-fizică" ${ }^{\prime 176}$.

Pe de altă parte, orientată spre privilegierea învăţământului ştiințific și tehnic este și încercarea de a crea pentru aceste instituții un corp profesoral de sinestătător, așa cum transpare din Decretul nr. 312 pentru reglementarea unor norme tranzitorii în legătură cu funcționarea instituţiilor de învățământ superior:

„Ministerul Învățământului Public este autorizat, pentru anul școlar 1948-1949, să ia, în înțelegere cu ministerele de resort, următoarele măsuri: a) să numească la Instituțiile Superioare de Învățământ, suplinitori de catedre, conferințe și în posturile de personal ajutător, persoane cu reputație științifică de specialitate din afara cadrelor didactice ale invățământului superior; b) să delege, în funcție de rector şi decan, la aceleași instituții şi pe membrii corpului didactic, numiți potrivit prevederilor primului aliniat; c) să încadreze toate facultățile în structura fixată, cu personal didactic necesar trecând la nevoie, personalul didactic existent, de la o facultate la alta" ${ }^{" 177}$.

Acest efort este cu atât mai accentuat, cu cât, mai ales în cazul facultăţilor socio-umane din universități s-au desființat catedre, au fost create altele noi, dar mai ales a continuat eliminarea vechilor profesori, inclusiv a celor intraţi între 19441948, pe criterii și motive dintre cele mai diverse, cu un punct comun în suspiciunea generalizată că nu prezentau încredere. În anii universitari 1948-1949 și 1949-1950 eliminările din învățământ au continuat să fie făcute sub forma îndepărtării unor profesori ca urmare a desființării catedrelor lor.

\footnotetext{
${ }^{176}$ Ovidiu Bozgan, op. cit., p. 86.

${ }^{177}$ Monitorul Oficial, nr. 261, 9 noiembrie 1948, p. 9014.
} 
Date sigure dar incomplete au rezultat după studierea, în special, a arhivei rectoratelor Universității „Al.I. Cuza” din Iași și „C.I. Parhon”, din București. Dacă la începutul anului universitar 1949-1950 de la Universitatea „Al.I. Cuza” au fost îndepărtaţi profesorii: George Costeanu, Nicolae Lupu, Nicolae Grămadă, Gheorghe Plăcințeanu, Ilie Popescu Spineni, I.B. Constantinescu, Gh. Mihai, Nicolae Tanoviceanu, conferențierii F. Horovitz, Natalia Șendrea, asistenții Al. Negoiescu, Iulia Mestecan, M. Cichină, Jana Martiniuc, spre sfârșitul acestuia, sunt licențiați: Ion Țurcanu, Constantin Angelescu, Ion Luca Georgescu, Grigore Teodoru, Vasile Hurghișiu, Vasile Viespescu, Ioan Popovici, Octavian Ionescu (Facultatea de Științe Juridice) și Emil Diaconescu de la Facultatea de Filologie ${ }^{178}$.

În paralel, printre universitarii bucureșteni puși în disponibilitate s-au aflat Mihnea Gheorghiu, Tache Papahagi, Mihai Bădulescu, Alexandru Vălimărescu, Mircea Florian, Anton Dumitriu, Valeriu Ciobanu, Ovidiu Papadima, Alexandru Piru, Horia Ursu, Penelopa Hulubei, Cornelia Badea, Matei Biloiu, Em. Constantinescu ${ }^{179}$.

Totodată, fără a încerca să trasăm limite cronologice foarte stricte, se poate obseva că, peste toate acestea se suprapune și ampla campanie de verificare a membrilor de partid, declanșată în urma ședinței din 27 iulie 1948 a Secretariatului C.C. al P.M.R., campanie care a durat până în aprilie $1950^{180}$ și a fost extinsă asupra mai multor categorii profesionale, între care și profesorii din Universități ${ }^{181}$. De asemenea, nu greșim în a afirma faptul că, după această dată, valurile de eliminări, demascări și intimidări au fost sincrone cu evoluțiile de pe scena politică: îndepărtarea „deviaționiștilor de dreapta” (1952), contracararea influenței din Revoluției din Ungaria în spațiul universitar (1956) și a „destalinizării” încercată de Miron Constantinescu și Iosif Chișinevschi (1957), retragerea trupelor sovietice în vara anului 1958 din România.

\section{Concluzii}

\footnotetext{
${ }_{178}$ Dănuț Doboș, Epurări la Universitatea din Iași 1949-1960 în Arhivele Totalitarismului, Anul II, nr. 1-2/1994, București, Editura Academiei Române, 1994, p. 46).

${ }^{179}$ Adina Berciu-Drăghicescu, Istoria Universității din București Documente 1864-1972,

București, Editura Universităţii din București, 2008, pp. 381-382.

${ }^{180}$ Vezi pe larg, Ștefan Bosomitu, „Puțini am fost, mulți am rămas”. Preliminarii la o sociologie $a$, ,ilegaliștilor" comuniş̧t în Institutul de Investigare a crimelor comunismului și Memoria Exilului Românesc, Incursiuni biografice în comunismul românesc, Iași, Editura Polirom, 2017, pp. 279-305.

181 În privința acestui din urmă aspect, începând cu primăvara anului 1950, au fost emise instrucțiuni ale Ministerului Învățământului atât pentru cunoașterea amănunțită a cadrelor didactice cât și pentru aprobarea prin decizie ministerială a funcționării pe mai departe în învățământ a acestora (vezi pe larg, Dănuț Doboș, op. cit., pp. 45-46).
} 
Problema înlocuirii și a transformării treptate a vechiului corp universitar cu unul aliniat ideologiei comuniste a avut o importanță crucială în perioada premergătoare instituţionalizării comunismului, îmbrăcând mai multe forme pe care am încercat să le identificăm și să le prezentă în toată complexitatea lor.

Dacă epurările petrecute în învățământul superior imediat după 23 august 1944 au avut în vedere, cu unele excepții, pe acei profesori și asistenți a căror implicare în Mișcarea Legionară sau regimul antonescian era arhicunoscută, alte schimbări din intervalul 1944-1948 au avut un substrat politic cât se poate de clar şi, mai ales, au fost insiduos materializate prin decizii ale Ministerului Învățământului.

În perioada premergătoare reformei învățământului din 1948 principalele direcții de acțiune în privința instituirii controlului politic asupra învățământului universitar au fost următoarele:

- numirea de către Ministerul Educației Naționale, pe termen de un an, atât a rectorilor, prorectorilor, decanilor, prodecanilor și a membrilor Senatelor Universitare;

- modificarea Legii nr. 386 relativă la organizarea învăţământului superior din 19 mai 1942 prin Decretul-Lege nr. 658 din 24 august 1946 în scopul creării posibilității ocupării catedrelor universitare de către cei aflaţi în siajul Partidului Comunist dar care nu îndeplineau toate criteriile profesionale necesare;

- eliminarea profesorilor universitari indezirabili Partidului Comunist, sub pretextul raționalizării cheltuielilor salariale din instituțiile de învățământ superior prin nu mai puțin de cinci decizii ale Ministerului Educaţiei Naţionale emise între 4 și 14 octombrie 1947, a punerii în disponibilitate a celor care nu au depus jurământ de credință noii Republici Populare Române și a comasării în data de 2 aprilie 1948 a Facultăților de Teologie de la Suceava și București.

- restructurarea și politizarea instituțiilor de învățământ superior în baza dispozițiilor Decretului nr. 175 din 3 august 1948 cu efect în continuarea îndepărtării vechii elite universitare considerată nesigură.

Ideologizarea excesivă a învățământului de toate gradele, instaurarea monopolului de stat asupra acestuia, diminuarea rolului educativ a disciplinelor umaniste a fost aşadar însoțită de eliminarea, pe criterii politice, a unei întregi elite universitare umaniste. Aceasta din urmă nu a avut efecte directe doar în marginalizarea sa socială în măsura în care a fost lipsită de alte posibilități de 
afirmare profesională, dar a avut efecte dintre cele mai nocive și îndelungate asupra întregii societăți. 